\title{
Globalization of the Natural Gas Market on Natural Gas Prices in Electric Power Generation and Energy Development
}

\author{
Thomas J. Hammons \\ International Practices for Energy Development and Power Generation, \\ University of Glasgow, \\ Scotland, UK
}

\section{Introduction}

The world's natural gas market is rapidly global zing. Traditionally, gas supplies for electric power generation have been delivered entirely within regional markets - usually with little geographical distance between the source of gas and its ultimate combustion. However, a significant and growing fraction of world gas is traded longer distances via pipeline and, increasingly, as LNG. The rising role of LNG is interconnecting gas markets such that a single global market is emerging.

This chapter discusses in a form not referenced in the literature in a convenient form heretofore the impacts of this globalization on the power generation industry. The electricity supply industry is increasingly turning to natural gas fuelled plants. Discussed in relation to the major gas producing and gas consuming regions is demand, infrastructure, price impacts and the possible responses of the power industry.

\section{Modeling and analyzing impact of interdependency between natural gas and electricity infrastructures}

With increasing investment in natural gas powered generation technologies, limitations in gas delivery capabilities are becoming increasingly relevant to operational planning of electric power systems. Thus it is essential to model and analyze the impact of the interdependency between natural gas and electricity infrastructures. Through integrated modeling of the two infrastructures, critical energy infrastructure vulnerabilities can be identified, thereby providing useful information for future planning of the natural gas delivery system and the electric power system.

A nation's energy security and sustainability that depends primarily on its energy infrastructure's security and sustainability are of critical importance to a nation's economic competitiveness and the improvement of people's daily lives. Natural gas infrastructure and electricity infrastructure are two essential elements of the nation's energy infrastructure. 
It is reported that the majority (up to $90 \%$ ) of the electric power plants that were built in recent years and will be built in the future are fuelled by natural gas [1,2]. By 2030, generation by natural gas is expected to increase by $230 \%$, the greatest relative increase of any generation technology [3].

Such rapid deployments have intensified the physical and economic interdependencies between natural gas and electricity infrastructures, which have introduced additional challenges for managing the security of such interdependent infrastructures. Specifically, the emergence of a large quantity of gas-fired units necessitates a more extensive gas supply and transmission infrastructure. This could greatly increase the vulnerability of gas pipeline infrastructure from the security aspect, and increase demand and thus market prices of natural gas from the economic viewpoint. There is evidence that natural gas usage for electric power in the summer may have a noticeable impact on working natural gas in storage and winter gas availability.

Conversely, the limitations of the gas delivery system become increasingly relevant to power system operations with the increased reliance on natural gas. An interruption or pressure loss in gas transmission systems could lead to a loss of multiple gas-fired electric generators that could jeopardize power system security. In the event of outages in gas transmission or power transmission systems, inconsistent control, monitoring, and curtailment procedures in the energy infrastructure could further constrain operations and may lead to cascading outages and blackouts.

The two infrastructure systems have become highly interdependent [4]. Gas market prices have a direct impact on unit commitment and economic dispatch in security-constrained power system operation. Changes in gas prices may mean the difference between using gas-fired units, or units which rely on coal or other fuels.

A framework for modeling the interdependency between natural gas and electricity infrastructures and impact of such interdependency on the economics and security of electric power system operation is necessary [5].

\subsection{Modeling the Interdependency between natural gas and electricity infrastructures}

\subsubsection{Gas network model}

Pipeline Flow: Gas pipelines are defined as either passive, for pipelines without a compressor, or active. For passive pipelines, the gas flows are determined only by the pressure difference. For active pipelines, a compressor allows the flow to exceed the pressure difference. Additionally, for active pipelines, the gas can only flow in one direction. A detailed mixed-integer-programming (MIP) based formulation can be found in [5].

Gas Contracts: Gas contracts may be modeled as interruptible, where the gas customer pays only for the amount of gas used, or take or pay, where the gas customer pays a fixed cost in advance for a specified amount of gas. In both cases, the total gas usage must be less than or equal to the contract amount. For interruptible contracts, the gas customer pays a fixed perunit price for the amount of gas used. For take-or-pay contracts, the gas customer pays a single fixed amount regardless of the gas actually used. Mathematical formulation for modeling gas contracts can be found in [5]. 


\subsubsection{Electrical network model}

The short-term operation of the electrical network can be simulated using a securityconstrained unit commitment (SCUC) model. The objective of SCUC is to determine a dayahead unit commitment (UC) for minimizing the system operating cost while meeting the prevailing constraints listed as follows:

1. Power balance

2. System spinning and operating reserve requirements

3. Minimum up/time limits, ramping up and down rate limits, start-up and shutdown characteristics of units

4. Must-on and area protection constraints

5. Fuel and multiple emission constraints

6. Transmission flow and bus voltage limits

7. Load shedding and bilateral contracts

8. Limits on state and control variables

9. Scheduled outages.

A complete model can be found in [6-8].

\subsubsection{Gas pipeline and electrical network interdependency}

The coupling constraints between the gas and electrical network are the flow conservation constraints: the total gas entering a node is equal to the sum of the gas leaving the node and the total gas withdrawal. The inclusion of the flow conservation constraints enables gas usage limits to vary as a function of gas flow limitations instead of being fixed values. The current operating limitations on gas usage can therefore be directly represented in the problem. Mathematical formulations for the gas flow conservation constraints are given in [5].

\subsubsection{Solution to the integrated gas network and electrical network model}

The addition of gas pipeline network modeling to SCUC will increase the size of the optimization problem in terms of number of variables and constraints. SCUC with gas pipeline network modeling is decomposed into two sub problems: UC and network analysis (NA). The UC problem is formulated for various types of generating units including thermal, combined-cycle, fuel switching, hydro, pumped storage, and renewable resources (wind or photovoltaic). The gas pipeline network model is incorporated as additional constraints in the UC problem for considering interdependency on gas network. A detailed MIP approach is applied to calculate the hourly unit commitment. The NA sub problem conducts security analysis based on the UC solution and coordinates with the UC problem through shift factor based method [9] or Benders decomposition [6,7].

\subsection{More realistic modeling}

As the electricity industry becomes more and more dependent on natural gas-fired generation, limits in the natural gas delivery system are becoming increasingly relevant to power system operation. 
The incorporation of natural gas network modeling is a start to comprehensively analyze the interdependency between the natural gas and electricity infrastructures. The gas network model suggested here is a very simplified model. Gas storage is not modeled; only gas usage for electric power production is considered; other non-power gas usages, such as residential and commercial, and the associated impacts are not modeled. A more detailed gas network model should be employed for a more realistic study on a practical system, for which the availability of data may be an issue. In addition, the impact of the interdependency between natural gas and electricity infrastructures mainly from the perspective of power system operation should be considered as should impact of such interdependency on gas network operation.

\section{Generation development options in United Kingdom (UK) from the aspect of natural gas availability and prices}

The tendency in West Europe to use more natural gas for heating and electrical generation could be boosted by further development in the European gas market. The considerable number of new pipeline and gas storage projects as well as constructive regulatory activities indicates that gas supply could be significantly increased.

Developing a competitive and regulated gas market supported with significant infrastructure investments and fulfilled environment requirements provide the framework to encourage increase in use of gas in the UK. From the aspect of energy resources diversity it appears that there is sufficient room for growth of CCGT and CHP plants to keep the right balance of generation mix.

The effect of gas market reforms on the power sector, particularly on generation mix in combination with industrial and heating requirements in the UK is now discussed. Optimum generation mix considers choice of fuel supply on a long-term basis via the analysis of remaining reserves and predicting market trends.

\subsection{Energy demand and supply in Europe and United Kingdom}

Annual energy demand growth projection in Europe is expected to be between 1.0 and 1.2 per cent in the next twenty years. Local electricity production, however, has a relatively low prospect for growth. It is expected that local sources will be insufficient to meet energy demand in the medium and long term. This combination of demand growth and local supply decline creates a need for a half a million billion cubic meters of new gas supplies in Europe.

Significant new supplies to Europe and UK are required and consideration has been given to pipelines from the North (Russia and Norway), East (ex Soviet countries via South East European corridor) and South (North African countries).

It is expected that gas would come from new developments in West Siberia (Yamal from 2012) and the Russian Barents Sea, pipelines through the Black Sea, the South East European (SEE) countries and over the Mediterranean Sea from Africa to Italy.

The electricity sector is one of the largest sectors of most European countries and could claim up to a half of the total capital investment. On average, electrical generation claims 
one third of countries total fuel consumption. On the other hand the total power generation of the developing world (including Asia, Latin America and Middle East) is expected to be over 60 per cent of the world's total.

From the projection of fuel inputs to power generation, coal and gas today represent about $66 \%$ of fuel inputs, and by 2030 it is expected that it will reach over $70 \%$.

\subsection{Gas market - Brief overview}

The main participants in the gas industry are suppliers, infrastructure owners, distributors and consumers. Most of the existing contracts for supply of gas to the distributors in Europe and UK are long term contracts based on steady increase in demand. The current pressure to supply local areas with gas and electricity at a new development pace requires fast response from the suppliers, which is difficult to achieve at competitive prices under the existing contract terms. Hence major changes are expected in restructuring of those contracts to reflect the dynamic changes in heat and electricity demand. The new open market would also need to adjust by providing prompt changes in price in accordance with the demand and supply.

The changes in the gas supply industry are visible in that the suppliers now tend to target more than one market. In an open market the consumers would equally have a choice of suppliers that would therefore result in a reduction and optimization of prices.

\subsection{Generation options in UK}

\subsubsection{Planning principles}

Figure 1 illustrates a relationship between the main factors in a country's economy at various levels.

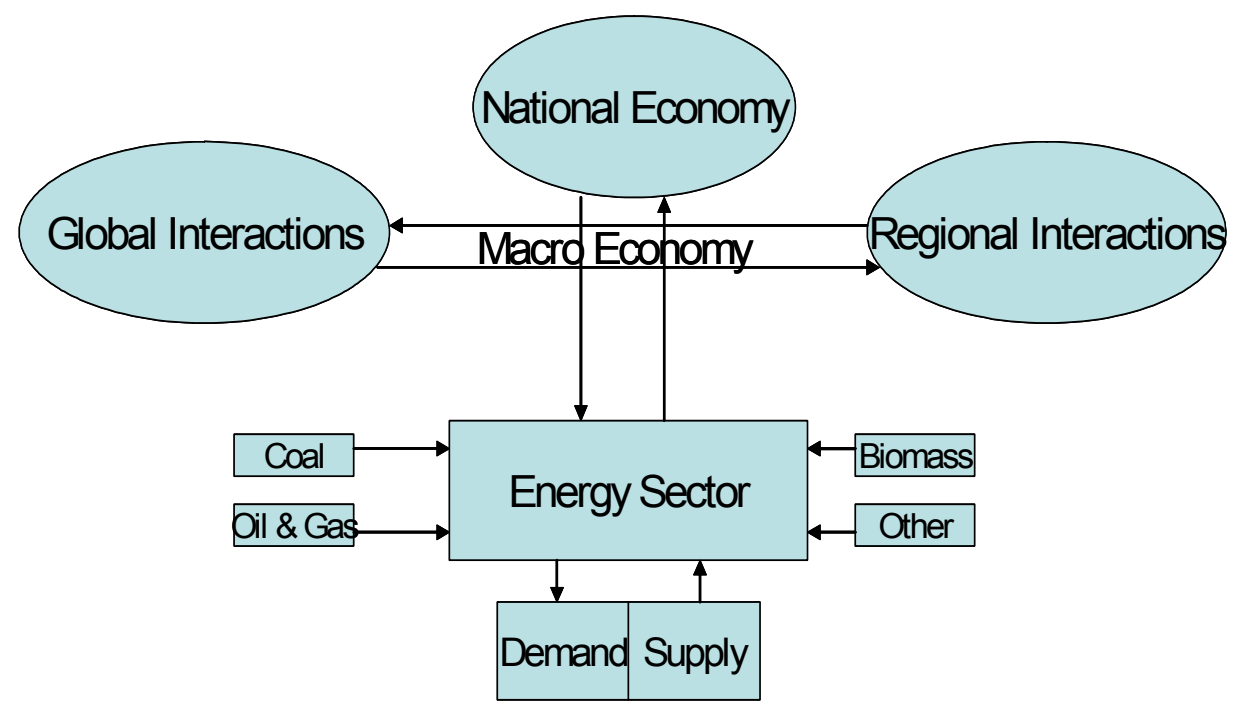

Fig. 1. Macro Economy Factors 
It is seen that a macro economy based strategy is related to national economy with strong ties with the energy sector with a strong influence and interactions at regional and global levels.

Electricity is a major sub-sector of Energy, which together with other sectors such as agriculture, transport, health and education greatly affects the national economy. Electricity is irreplaceable in many areas and plays a strong role in expansion of the sectors and therefore its development is of crucial importance for a country's economic growth.

The main generation planning principle is to provide supply to meet the predicted demand in the most economic way in accordance with the adequate security and safety standards. Integrated Resource Planning (IRP) [10] is a recognized process that identifies a mix of resources to meet the future electricity service needs of the consumers, economy and the society.

Table 1. compares the various sources of energy participating in generation in UK and Europe. There is a significant effort to increase the use of sustainable sources.

\begin{tabular}{|c|c|c|c|c|c|c|c|c|}
\hline & $\mathrm{N}$ & $\mathrm{CL}$ & $\mathrm{P}$ & $\mathrm{NG}$ & $\mathrm{H} / \mathrm{W}$ & $\mathrm{B}$ & Other & Total \\
\hline & $\%$ & $\%$ & $\%$ & $\%$ & $\%$ & $\%$ & $\%$ & '000 GWh \\
\hline UK & 22 & 34 & 2 & 37 & 2 & 1 & - & 386 \\
\hline EU & 33 & 25 & 6 & 17 & 15 & 2 & 2 & 2671 \\
\hline
\end{tabular}

N-Nuclear; CL-Coal Lignite; P-Petrol; NG-Natural Gas; H/W-Hydro/Wind; B-Biomass Source: Wikipedia; comparison of emissions from various energy sources.

Table 1. Electricity Generation in UK and Europe

Nuclear technology in the UK is likely to rise to $33 \%$ in the next $10-15$ years in accordance to governmental predictions. Consideration has also been given to use of coal and lignite with new technologies that would purify the fuel and increase the plant efficiency. Exchange of experience with countries using those technologies in Europe, such as Poland and Russia, may lead to reopening of some coal mines and result in maintaining coal's share of current electricity production in UK.

The UK is committed to reducing the emissions of greenhouse gasses (GHG) as per the Kyoto protocol. The mechanisms to import clean energy from the countries with high margins (mainly developing countries in Eastern Europe) are also on the agenda.

Future electricity generation technologies will aim at achieving clean emissions in order to reduce impact on the environment, achieve high efficiency and short lead times to minimize uncertainties and risks. CCGT as well as CHP fully comply with this requirement. CHP technology is more common in Sweden, The Netherlands, Germany and Austria due to the high demand in heat for longer winter periods.

The main advantages of the gas turbine generation are:

- There is more choice for location for gas power plant.

- $\quad$ Gas plants and CHP can operate in peak shaving mode due to its fast response.

- $\mathrm{CHP}$, which is capturing waste heat and reusing it in an industrial process, is considered as the most efficient type of generation. 
Conversely, the main disadvantage is that the availability and prices of gas will always be associated with risks related to disintegrated markets and political stability of the countries with the gas source as well as countries associated with gas transmission.

\subsubsection{CHP plants in UK}

Most thermal plants worldwide produce electricity with very low efficiency i.e. of the order of $33 \%$. This has prompted concerns regarding high emissions of global warming gasses due to the GHG effect with evident local, regional and likely global implications. Due to those climate change initiatives, the focus on modern electricity generation has shifted towards improving energy efficiency and reduction of pollution.

Table 2 illustrates the advantages of gas over fuel oil and coal in terms of air pollution emission.

\begin{tabular}{|c|c|c|c|c|}
\hline Fuel & $\mathrm{SO}_{2}$ & $\mathrm{NOx}$ & $\mathrm{CO}_{2}$ & $\mathrm{PM}$ \\
\hline Coal & 0.081 & 0.018 & 3.57 & 0.106 \\
\hline Oil & 0.06 & 0.017 & 3.13 & 0.004 \\
\hline Gas & none & 0.012 & 2.07 & none \\
\hline
\end{tabular}

[in mill tons/m.t.o.e of fuel]. PM-Particulate matter; $\mathrm{SO}_{2}$ sulphur dioxide; $\mathrm{CO}_{2}$ carbon dioxide; $\mathrm{NO}_{\mathrm{x}}$ nitrogen oxide

Source: Wikipedia; comparison of emissions from various energy sources.

Table 2. Air Pollution Emission

According to environmental agencies new CHP plants in the UK can deliver cost-effective carbon savings between 4 and 6 million tonnes and up to 8 million tonnes by 2015 .

From the technical point of view they provide fast response to generate into the system, which fits nicely in the new regulated and more dynamic gas market. Gas turbines are generally more reliable than pure sustainable sources.

\subsection{UK legislation and policy}

\subsubsection{Energy review}

The UK Government's report on 'The Energy Challenge' was issued on 11 July 2006. The main objective is to meet two major long-term challenges in UK energy policy, namely (i) climate change by reducing carbon dioxide emissions and (ii) to deliver secure, clean energy at affordable prices, as UK moves to increasing dependence on imported energy.

The consultation on the new measures on gas security of supply took place from 16 October 2006 to 12 January 2007. This consultation discussed:

- the effectiveness of current gas security of supply arrangements

- their robustness as UK moves to higher dependence on gas imports over the next 10-15 years

- $\quad$ whether new measures are needed to strengthen them.

The document considers details on the security of gas supply and examines the extent to which the current policy framework is likely to deliver security of supply. 
It also assesses the new challenges faced as the flexible sources of gas in the UK decline and discusses views on the costs, benefits and risks of some possible adjustments to the current commercial and regulatory framework to strengthen the ability to rise to that challenge.

A number of other consultations have been launched to help address security of energy supply and climate change challenges. A selection of a few is listed below.

- New nuclear policy framework, October 2006

- $\quad$ Energy Efficiency Commitment April 2008-March 2011, October 2006

- Proposals on banding, and amending the Renewables Obligation, December 2006 (part 2) and January 2007 (part 1)

- Measures to reduce carbon emissions in large non-energy intensive business and public sector organizations, January 2007

- $\quad$ Energy billing and metering, February 2007

- $\quad$ Resilience of Overhead Power Line Networks, March 2007

- $\quad$ Distributed energy, A call for evidence, January 2007

- A consultation on Offshore Natural Gas Storage and Liquefied Natural Gas Import Facilities. This consultation considers the need for, and provides views on, changes to existing legislation with regard to the storage of natural gas in non-hydrocarbon features (e.g. salt caverns), the storage of natural gas in hydrocarbon features (e.g. partially depleted oil and gas fields) and the unloading of Liquefied Natural Gas (LNG) offshore.

- Offshore Natural Gas Storage and Liquefied Natural Gas Import Facilities: consultation, February 2007.

On 15 December 2006, the Department of Trade and Industry (DTI), now Department for Business, Enterprise and Regulatory Reform (BERR), issued new Guidance to power station developers to maximize the use of CHP where feasible. In issuing this Guidance the Government is signaling its strong commitment to $\mathrm{CHP}$, whilst recognizing that it is up to the market to bring forward the most competitive proposals to help ensure security of supply. The outcome of this was fed into the Energy White Paper in 2007.

\subsubsection{Energy white paper}

The White Paper, published on 23 May 2007, sets out the Government's international and domestic energy strategy to respond to these changing circumstances, address the long term energy challenges we face and deliver our four energy policy goals:

- to put UK on a path to cutting $\mathrm{CO}_{2}$ emissions by some $60 \%$ by about 2050 , with real progress by 2020

- to maintain the reliability of energy supplies

- $\quad$ to promote competitive markets in UK and beyond

- to ensure that every home is adequately and affordably heated.

It shows how the measures set out in the Energy Review Report in 2006 have been implemented, as well as those announced since, including in the Pre-Budget Report in 2006 and the Budget in 2007.

Some of the measures in this White Paper require further public consultation. Alongside the White Paper consultations on nuclear power, the Renewables Obligation and guidance on the 1965 Gas Act have been launched. 
CHP plants are currently in the focus of energy experts as the alternative to failure of meeting the targets related to sustainable energy. Total CHP generated energy in UK in 2005 was 27TWh of electricity and 51TWh of heat. The UK government predicted that just over $10 \%$ could be generated out of total predicted energy of $350 \mathrm{TWh}$ with the trend to grow up to $17 \%$ as an ultimate potential. Other countries in Europe such as Germany, report that they expect $\mathrm{CHP}$ plants to meet $25 \%$ of the overall demand.

\subsection{Generation development options in UK}

The advantages of gas turbines over other sources are numerous from fast response to system requirements to acceptable ecological characteristics with low $\mathrm{NO}_{x}$ and no $\mathrm{SO}_{x}$ emissions. In terms of efficiency, CCGTs are considered the best of all thermal power plants with efficiencies up to $60 \%$. Further improvements, which is the trend in the UK, is to combine the gas turbine with use of sustainable sources of energy that would reduce the emission of GHG and improve efficiency up to $80 \%$ by connection to district heating and providing heat to industrial processes.

Liberalization of the European Gas Market opens the opportunity for gas to participate in UK's generation mix in developing more CHP in addition to already implemented CCGT.

Dependence on gas imports to replace UK reserves is most likely to be both pricey and vulnerable to the loss of supply due to political instability. It is prudent to plan for such a foreseeable situation by consideration of the following.

- Build modern Nuclear to replace existing operational old stations that could provide deficit that other low $\mathrm{CO}_{2}$ technologies cannot provide.

- Allow power generation from abated emission, modern coal power stations, as well as providing incentive to utilize more coalmine methane in gas engines.

- Continue promoting 'renewable' fuels and wind, wave and solar, whilst keeping in perspective the relatively low percentage of their overall contribution.

- Minimize output from existing gas fired power stations to retard the rate of consumption of Britain's own reserves - this may mean returning to a higher percentage of power generation from coal, having "clean coal" technology.

- Adequately fund development of tidal and under sea current technologies, for predictable power generation.

- Government policy with regard to the structure of the energy markets should aim to remove the short-term price horizons in those markets that are a major bar to capital investments that depend on long tern return periods.

\section{US and Canadian liquefied natural gas}

US and Canadian gas consumers are averse to long-term physical contracts - the traditional mechanism for securing liquefied natural gas (LNG) in the world market. The US and Canadian natural gas market is wedded to spot transactions. This is partly a reaction to costly experiences unwinding long-term, reserve-based, bundled supply and transportation contracts that were well above spot prices a few decades ago, and partly a reflection of just how comfortable market participants have become in relying on the spot market whenever they need to buy or sell physical gas. 
The LNG industry, by contrast, is wedded to long-term contracts. Two drivers are responsible. First, long-term contracts with credit-worthy off-takers were necessary to underpin the large capital investments for the first several LNG projects. Second, buyers who must depend on LNG and are thereby displacing other fuels, require dedicated upstream resources; liquefaction trains and tankers for assurance the gas will be there when needed. The US and Canada (and the UK) attract supply with price, while Europe and Asia attract new supply with long-term contracts.

Flows of LNG to the US are not simply a function of the relative attractiveness of North American spot prices. The lack of US and Canadian commitment to LNG clashes with the dependency that North American countries will have on this new supply.

\subsection{Power sector need for LNG}

Power sector demand growth alone will boost the need for gas. Electricity consumption has grown at an annual average rate of $1.3 \%$ per year in the last decade. With the latest round of new power plant capacity more than $90 \%$ gas-fuelled, natural gas is serving a large and growing share of power sector demand growth. The outlook is for more with natural gas slated to serve the larger share of power plant additions ahead. Power sector use of gas added an average of 0.75 bcf per day of gas demand each year in the past decade (Figure 2).

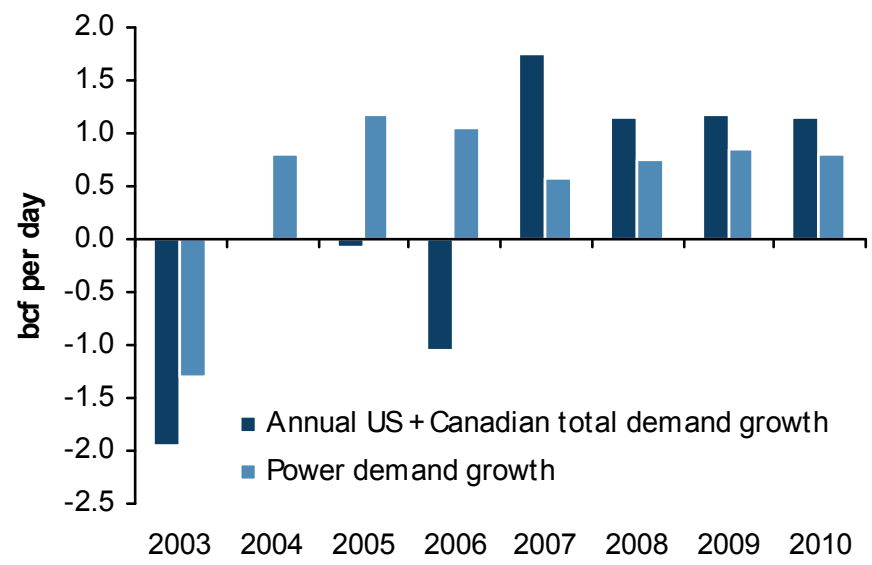

Source: EIA, Barclays Capital

Fig. 2. Gas Consumption in the Power Sector

\subsection{Global LNG supply boom}

The expected reliance of the US and Canada on LNG parallels two significant events in the LNG industry. The first is a boom in global LNG supplies. These have grown 9 bcf per day since the start of the last decade and are set to grow an additional 9 bcf per day by the end of the decade (Figure 3). The 5 bcf per day of LNG supply additions in 2008 would be the largest single year of supply additions in the industry's history. 
This boom in global LNG supply is facilitated by a second significant event - the intermediation of energy companies as supply off-takers for many new liquefaction projects. Sensing a growing global need for new LNG supply, a number of new supply projects were launched, with energy companies - rather than end-users - contracting for the new supply. There is essentially no unsold LNG supply from liquefaction projects that are under construction. Committing to LNG supply without an end-use buyer may be risky. The large, liquid US market provides a convenient destination of last resort for any supply that does not otherwise find an end-user by the time the liquefaction project comes on line.

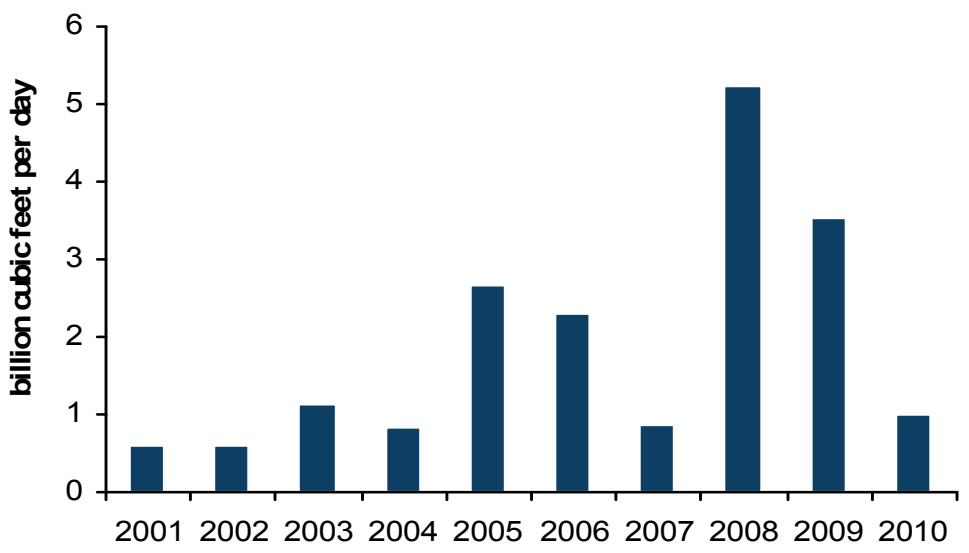

Source: EIA, Barclays Capital

Fig. 3. Global LNG Supply Growth

\subsection{Oil-indexation, Yen and Euros}

Energy company intermediaries have never intended to hold vast quantities of LNG supply for spot market sales. With global prices for natural gas remaining robust, and with strong demand growth for natural gas in non-North American markets, a growing number of new long-term contracts have allowed these energy companies to commit this LNG to end-users. These long-term end-user contracts allow the companies controlling the supply to reduce their risk, at prices that have proven to be desirable.

Beyond new, long-term LNG contracts to non-North American end-users, two additional powerful trends are driving LNG away from US shores. First, typical European and Asian long-term LNG contracts are linked to oil prices. With oil selling at an increasing premium to natural gas (Figure 4) oil-linked LNG in non-US markets carries an automatic premium to US Henry Hub at current market levels. Many countries that import LNG do not have functioning gas markets; thus, prices must be linked to another commodity, typically oil. Oil-linked LNG provides buyers and sellers an opportunity to hedge. The second trend is the strength of the yen and euro compared with the US dollar, with the dollar declining 9\% against the yen over the years (2005-2007), and falling 25\% against the Euro. 


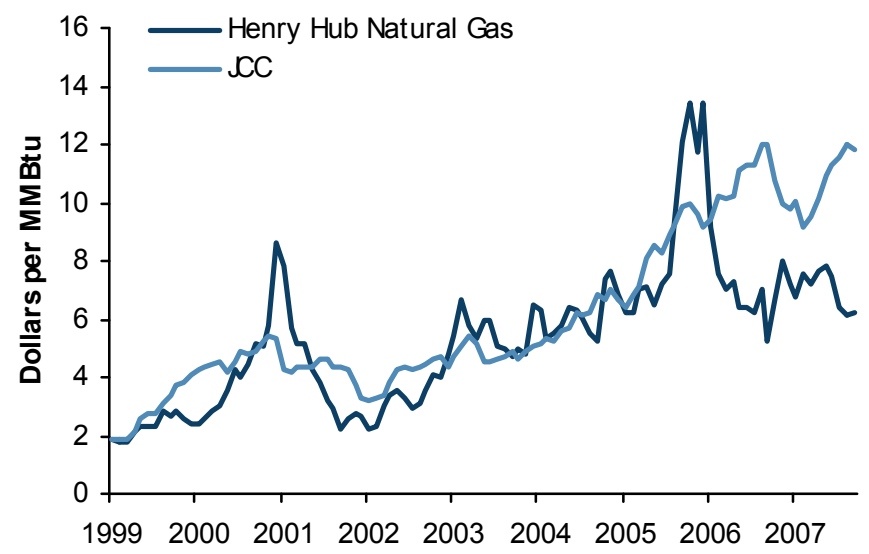

Source: EIA, Barclays Capital

Fig. 4. Growing Oil Premium to Natural Gas (Japanese Crude Cocktail (JCC) oil prices compared with US Henry Hub)

\subsection{Standby for LNG}

With US and Canadian end-users averse to long-term physical contracts for LNG the risk remains that, without committing to LNG, it may not be available if needed in the years ahead. It is unlikely that none would be available on a spot basis for a given sustained period in the years ahead, when forecast non-North American gas demand is compared with global LNG supply. Yet, there remains the risk that in any given period, LNG flows could fall to low levels, even zero, depending on events outside of North America. The US and Canada do not have control over LNG flows into their markets.

US and Canadian buyers should not rush out at this time to contract for LNG. This is because:

- Financial hedges combined with flexible, short-term physical supply offers fewer headaches for buyers and sellers.

- $\quad$ Some LNG contracts include marine risk (as part of force majeure); LNG tankers do not enjoy hurricanes, for example. This risk creates a challenge for some buyers.

- An energy supplier is more likely to offer a buyer portfolio gas rather than specifically LNG under a US-destined long-term physical contract.

- $\quad$ LNG is not necessarily cheaper than portfolio gas.

- If utilities continue to be judged on their purchase prices against the spot market, then a drought of LNG that pushes spot prices higher for everyone presents no inherent risk for a utility so judged.

- An increasingly smaller amount of LNG remains uncommitted. The opportunity available to sellers of Pacific LNG, for example, is a Japanese Crude Cocktail (JCC)linked price. No utilities are interested in signing oil-linked LNG contracts.

- A long-term contract represents a tremendous contractual liability of a buyer's balance sheet. 
Some utilities have a free-rider approach: let others bring the LNG to market, enjoy the downward price pressure that results, and buy it on the spot market.

\subsection{LNG imports to remain de-linked with US spot prices}

Global LNG supply growth will moderately outstrip non-North American consumption, allowing deliveries to the US to grow. Regasification capacity and shipping capacity pose no restriction to US imports. Regasification capacity, which registered substantial growth in 2008, should further outstrip available supply to fill it (Figure 5). Should economic growth boom overseas, particularly in Asia, LNG deliveries to the US would dwindle far below the amounts shown in Figure 5. Conversely, faster pace of LNG supply growth or more moderate rates of gas demand growth in the other fifteen LNG consuming countries would boost deliveries to North America.

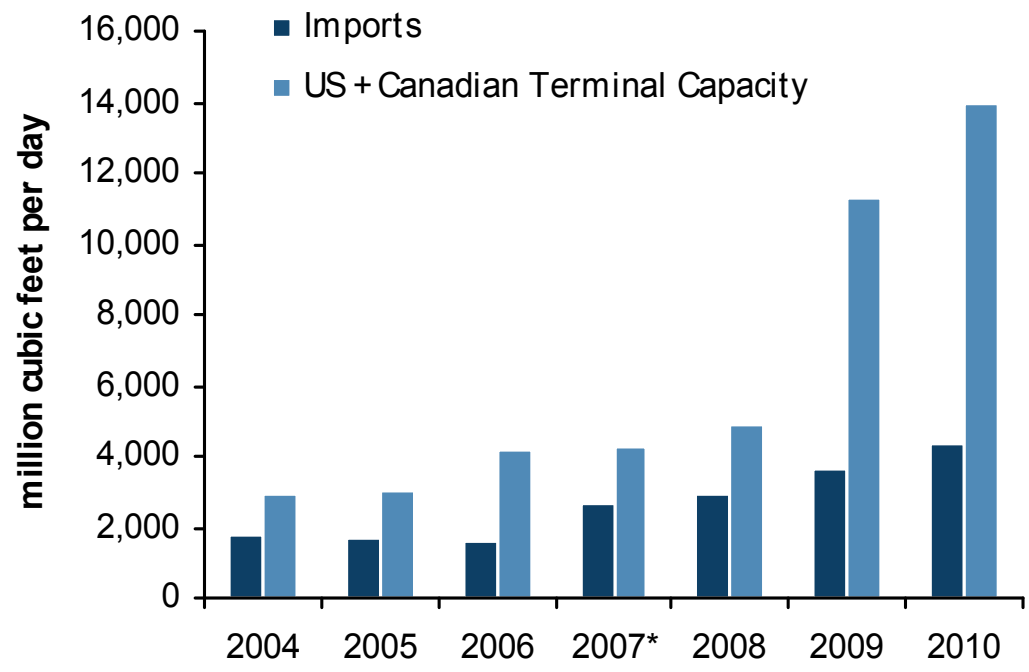

Note: *Estimated. Source: EIA, Barclays Capital

Fig. 5. US and Canadian LNG Imports versus Regasification Capacity

It is incorrect to add up all non-North American LNG supply contract volumes and assume these will not be available to the US and Canada. End-use LNG buyers contract for more supply than is needed. This allows surpluses to be marketed in the spot market. New LNG contracts offer greater flexibility to divert cargoes. The large storage market in the US provides a ready destination for surplus volumes. There have even been modest signs of interest in buyers securing LNG supply, notably in California. Thus, a growing slice of LNG supply can be marketed on a spot basis to buyers.

In competition for these supplies will be any market in need. Asian markets, which typically clear on volume and not price, have shown a penchant to out-bid these spot cargoes. European buyers have shown more price responsiveness, while the UK market operates much as the US and Canadian market, with spot pricing. 


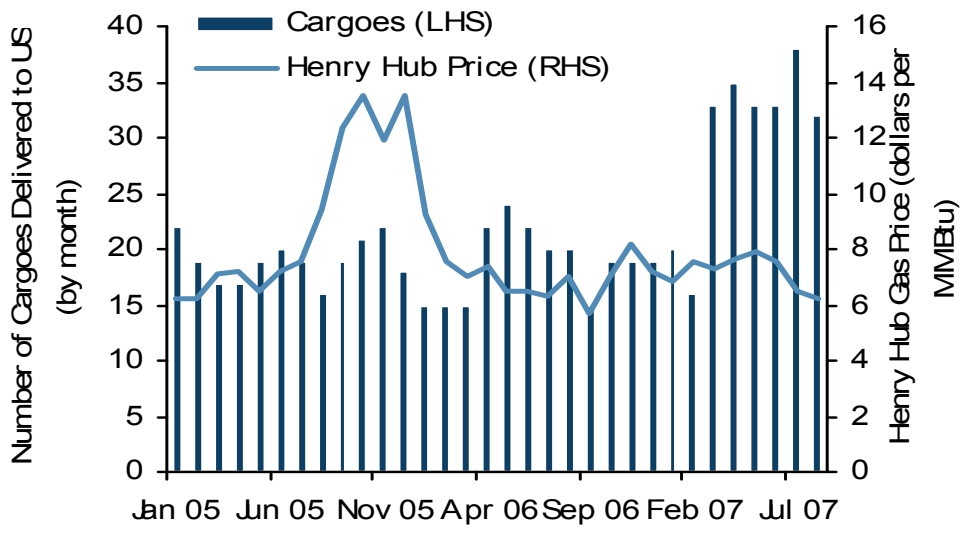

Source: EIA, NYMEX, Barclays Capital

Fig. 6. US LNG Imports versus Gas Prices (Henry Hub)

This standby method of purchasing LNG attracts it to the US at some times, and not at others. Figure 6 illustrates the historical relationship between US pricing and LNG deliveries. Spot prices are not the primary driver of flows into the US. The general trend in increased deliveries in 2007 was due to more available spot LNG supply, not stronger US prices.

With US and Canadian end-users averse to long-term physical contracts for LNG the risk remains that, without committing to LNG, it may not be available if needed in the years ahead. It is unlikely that none would be available on a spot basis for a given sustained period in the years ahead, when forecast non-North American gas demand is compared with global LNG supply. There remains the risk that in any given period, LNG flows could fall to low levels, even zero, depending on events outside of North America. The US and Canada do not have control over LNG flows into their markets.

Energy information and the New York Mercantile Exchange information is available at the websites: (i) Energy Information Administration (EIA), "International Energy Outlook 2007, www.eia.doe.gov. and (ii) New York Mercantile Exchange (NYMEX), www.nymex.com .

\section{Impact of natural gas market on power generation development in Russia}

This Section discusses the natural gas market and its impact on power generation development in Russia

A large part of natural gas consumed in Russia is used for electricity and centralized heat production. Table 3 presents gas volumes consumed in 2005 in Russia for electricity and heat production [11].

Of 397 bln $\mathrm{m}^{3}$ of natural gas used in Russia in 2005, electricity and heat generation required 243 bln $\mathrm{m}^{3}$ or $61 \%$; the remaining $39 \%$ was used by the population and other branches: metallurgy, petro-chemistry, agro-chemistry, etc. Almost the same relation in shares has been observed in recent years. 


\begin{tabular}{|l|c|}
\hline \multicolumn{1}{|c|}{ Type of final energy and generation sources } & \multicolumn{1}{c|}{$\begin{array}{c}\text { Gas consumption } \\
\text { mln. tce } / \text { bln.m }\end{array}$} \\
\hline Electricity supplied by fuel-fired power plants & $129 / 112$ \\
\hline Heat supplied by fuel-fired power plants & 65.9 / 57 \\
\hline Heat supplied by industrial and residential boiler plants & $81.8 / 71$ \\
\hline $\begin{array}{l}\text { Heat supplied by boiler plants of agricultural } \\
\text { enterprises }\end{array}$ & $2.7 / 2$ \\
\hline Total: & $270.4 / 243$ \\
\hline
\end{tabular}

*tce - ton coal equivalent

Table 3. Gas Consumption for Electricity and Heat Production in Russia in 2005

Table 4 indicates the structure of fuel consumption by the generation companies of RAO "EES Rossii" in 2000-2006 for electricity and heat production. It is virtually impossible in Russia to consider separately the production of electricity and centralized heat at cogeneration plants (CPs), because almost $1 / 3$ of electricity is generated in combination with heat at thermal power plants (TPPs).

\begin{tabular}{|l|c|c|c|c|c|c|c|}
\hline & 2000 & 2001 & 2002 & 2003 & 2004 & 2005 & 2006 \\
\hline Gas, bln. $\mathrm{m}^{3}$ & 127.1 & 131.2 & 132.4 & 135.6 & 139.7 & 142.6 & 148.1 \\
\hline Fuel oil, mln. t & 8.5 & 7.6 & 7 & 6.8 & 53 & 49 & 6.2 \\
\hline Coal, mln. t & 120.1 & 109.6 & 106 & 109.3 & 101.2 & 104.4 & 109.2 \\
\hline
\end{tabular}

Source: Annual reports of RAO "EES Rossii"

Table 4. Structure of Fuel Consumption by Subsidiary Generation Companies of RAO “EES Rossii" in 2000 - 2006

Conversion of data from Table 4 to standard fuel enables the share of each resource of fuel supply to be indicated for the generation capacities. This is indicated in Figure 7.

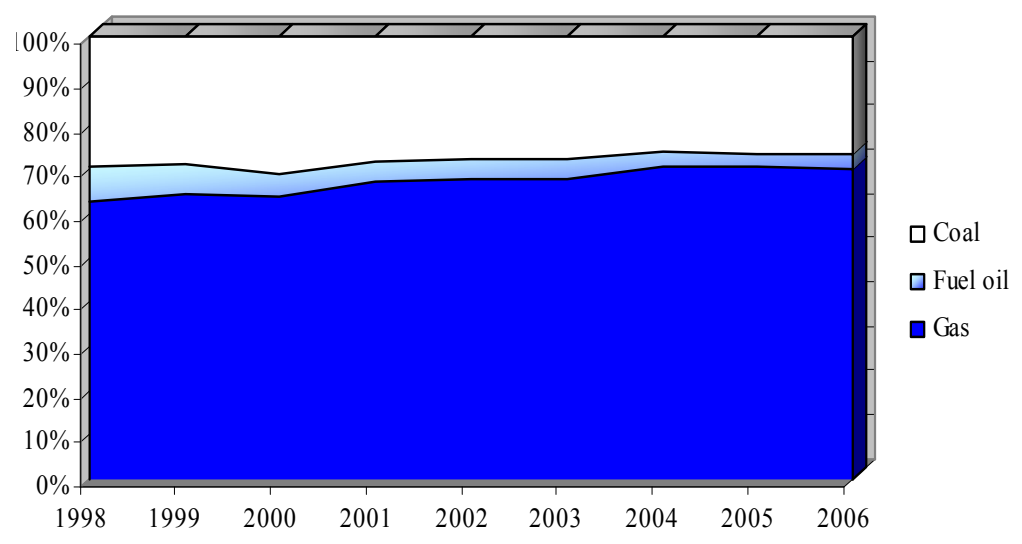

Fig. 7. Share of individual fuel resources in fuel supply for generation capacities of RAO "EES Rossii" 1998-2006 
Figure 7 shows that over these 8 years (1998-2006) the share of natural gas used for the production of electricity (and centralized heat at cogeneration plants) at thermal power plants increased from $63 \%$ to $70 \%$.

For the same period the price of gas supplied to industrial consumers and power plants increased from $\$ 10 / 1000 \mathrm{~m}^{3}$ to $\$ 51 / 1000 \mathrm{~m}^{3}$ (the last figure is for 2007). Note that the indicated prices are controlled and are several times lower than those for European countries and USA.

Such a situation for gas prices in Russia cannot last long. Prices will inevitably rise because of the following:

- The tendency of RAO "EES Rossii" to achieve equal profitability of the gas industry in the external and domestic gas markets (in 2006 the gas price in the European countries was at the level of $\left.\$ 250 / 1000 \mathrm{~m}^{3}\right)$;

- $\quad$ The price increase will be caused by objective necessity for Russia to move to new (with very expensive development) areas of natural gas production (the Yamal and Gydan Peninsulas, shelves of the Barents and Kara Seas). This seems to be the main reason for price increase.

The necessity to sharply increase domestic gas prices is also understood by the Government of the Russian Federation (RF). The change of wholesale domestic gas prices to year 2010 was determined on 30 November 2006. Based on different factors (depletion of the main gas fields in the current gas production areas, growth of gas demands, aging of fixed production assets, growing demands of the industry for investments, etc.) the gas price level for industry and the electric power industry in 2011 will approach $\$ 115 / 1000 \mathrm{~m}^{3}-\$ 120 / 1000$ $\mathrm{m}^{3}$. Further, the possibility for including the gas price formula (approved by the Federal Tariff Service of RF in July 2007) in long-term contracts for domestic consumers is examined at present [12]. (It will take into account primary cost of gas of a concrete gas production area in a concrete gas consumption area including the necessary charges, taxes, and dues). The average gas price calculated by this formula was about $\$ 170 / 1000 \mathrm{~m}^{3}$ in 2007. Prior to 2007 this price was hypothetic, in 10-15 years such a price will be real for the reasons mentioned above.

\subsection{Cost of primary gas for the main gas fields}

Table 5 gives values of cost of primary gas for the main gas fields of the Yamal Peninsula (Bovanenkovskoye and Kharasaveyskoye), the shelf of the Kara Sea (Leningradskoye and Rusanovskoye) and the fields of the Gydan Peninsula in the Moscow region (i.e. in the center of the European part of Russia) that were calculated at the Energy Systems Institute, Irkutsk, Russia.

The prime cost of gas for the above field (Table 3) represents the relation between the total capital and operating costs for the whole time period of infrastructure creation on the field and the total gas production for the same time period. Here the total costs are the costs for creation and operation of:

- Production and social infrastructure required for development of the considered field and later on - its exploitation;

- Systems of gas production and preparation for long-distance transportation;

- Systems of long-distance gas transportation from the field to the area of its consumption. 


\begin{tabular}{|l|c|c|c|c|c|}
\hline \multirow{2}{*}{ Field } & \multicolumn{3}{|c|}{ Prime cost components } & \multicolumn{2}{c|}{ Prime cost } \\
\cline { 2 - 6 } & Development & $\begin{array}{c}\text { Production } \\
\text { and } \\
\text { preparation }\end{array}$ & Transport & $\begin{array}{c}\text { Rass of } \\
\text { posible } \\
\text { values }\end{array}$ & $\begin{array}{c}\text { Average } \\
\text { values }\end{array}$ \\
\hline $\begin{array}{l}\text { Bovanen- } \\
\text { kovskoye }\end{array}$ & $12-15$ & $30-35$ & $53-59$ & $95-109$ & 102 \\
\hline $\begin{array}{l}\text { Kharasa- } \\
\text { veyskoye }\end{array}$ & $12-15$ & $30-35$ & $54-60$ & $95-110$ & 103 \\
\hline $\begin{array}{l}\text { Lenin- } \\
\text { gradskoye }\end{array}$ & $18-20$ & $45-50$ & $60-67$ & $123-137$ & 130 \\
\hline $\begin{array}{l}\text { Rusanov- } \\
\text { skoye }\end{array}$ & $18-20$ & $45-50$ & $64-71$ & $127-141$ & 134 \\
\hline $\begin{array}{l}\text { Fields of } \\
\text { Gydan } \\
\text { Peninsula }\end{array}$ & $15-18$ & $35-40$ & $64-70$ & $114-128$ & 121 \\
\hline
\end{tabular}

Table 5. Primary Cost of Gas for the Main Fields of new Gas Production Areas in the Moscow Region, \$/1000 $\mathrm{m}^{3}$

The values of primary cost of gas in Table 3 were calculated on the base of the corresponding specific capital and operating costs that are reasonable only for the present day. Correspondingly, the obtained preliminary figures for primary cost of gas of new gas production areas should be considered correct only for the current gas production. At the time of actual start of gas production from the considered fields the figures can change because of the uncertainty factor.

According to Table 5, the most probable prime cost of gas in the Moscow region could make up currently $\$ 100 / 1000 \mathrm{~m}^{3}-\mathbf{-} \$ 105 / 1000 \mathrm{~m}^{3}$ (for Yamal), \$130/1000 m--\$135/1000 $\mathrm{m}^{3}$ (for the shelf of the Kara Sea) and $\$ 128 / 1000 \mathrm{~m}^{3}$ (for the fields of the Gydan Peninsula). It can be said with reasonable confidence that the specific capital and operating costs will increase with lapse of time and hence the primary cost of gas in new gas production areas will also rise. Based on different data for the period from 2000 to 2006 the indicated specific costs increased on the whole by $70--100 \%$. Even if the growth rates of specific costs for the period to 2020 are not so high and make up about $50 \%$ with respect to those for the present day, by 2020 primary cost of gas will increase to $\$ 150 / 1000 \mathrm{~m}^{3}$ for the Yamal gas, to $200 / 1000 \mathrm{~m}^{3}$ for the Kara Sea shelf and to $\$ 180 / 1000 \mathrm{~m}^{3}$ for the Gydan Peninsula.

In the foregoing, only the prime cost is discussed. Hence, the average gas price of $\$ 170 / 1000 \mathrm{~m}^{3}$ (that was calculated by the gas price formula) can be considered quite real in 10-15 years. So much so, the gas share in new gas production areas in 15-20 years will amount to $70--75 \%$ of the total gas production in the country.

Thus, the gas price rise in the domestic market of Russia, in particular for generation companies is inevitable. This will involve an increase in price of electricity generated and correspondingly an increase in price of all types of industrial products and service industries.

There are various methods by which this process could be dampened. One is to decrease the share of a costly resource (gas) in favor of one that is more financially accessible (in this situation it is coal). In addition, the increase in diversification of the fuel mix in Russia (gas 
share is $80 \%$ of total fuel consumption) will have a positive impact on the level of Russia's energy security.

\subsection{Structure of generation capacities for Russia considering increase in involvement of coal}

Using the required data, the change in share of gas-fired thermal power plants in the structure of generation capacities for Russia due to increase in the coal share can be evaluated. The data relates to:

- increase in gas price for Russia's electric power industry from $50 \$ / 1000 \mathrm{~m}^{3}$--currently to $170 \$ / 1000 \mathrm{~m}^{3}$ in 2020

- change in relationships between coal and gas prices (in terms of standard fuel) from 1:1.1--currently up to 1:1.6-1.8 in 2020

- national electricity demand, taken on the basis of the Energy strategy of Russia up to 2020 [13]

- technical and financial constraints on replacement of worn and obsolete generation equipment and construction of new capacities

- $\quad$ specific capital investments in the construction of new generation capacities of different types (gas- and coal-fired thermal power plants, nuclear and hydro power plants) and specific operating costs for currently operating and new capacities, etc.

A technique for electric power industry development planning which accounts for its interrelations with other branches of the Fuel and Energy Complex (FEC) in Russia has been developed [14]. It is similar to the integrated resource planning approach $[15,16]$. The approach is integrated planning of electric power systems and gas supply systems expansion in a market environment. Consideration is given to the practical approach of using such techniques in multi-step planning of Russia's power industry development, taking into account prospects for development of the national gas industry and bearing in mind the possible substantial rise in the price of gas used in the electric power industry.

Such multi-step modeling supposes two-level studies:

1. entire Fuel and Energy Complex of the country;

2. systems of electric power and gas supply.

At first level the territorial and production model of the national Fuel and Energy Complex (FEC) is employed to determine the main relationships between development of the fuel industries and the electric power industry, taking into consideration their interaction in the considered time horizon. Then, involving a more detailed mathematical model of electric power industry development, the prospective structure of generation capacities and their allocation are determined.

The next step assumes creation of scenarios of possible deviations in gas industry development from the basic conditions (considered at the FEC level). The scenarios are studied from the viewpoint of their impact on electric power industry development. Then, based on analysis of the studies and using alternately the models of FEC, electric power industry and gas industry, the solutions of potential electric power industry development 
that are adaptive to expected conditions of gas industry development (including changes in the gas prices within the set ranges) are determined. At the same time (at the FEC level) account is taken of the conditions for expansion of all types of generation capacities and development of all fuel industries - in terms of fuel inter-changeability and reserves.

Analysis of factors determining the structure of the generation capacities within multi-step modeling reveals that in addition to gas and coal prices themselves, the key factors for Russia (at least up to 2020) are physical capabilities of involving gas and coal in the fuel mix of the country. In turn the volumes of such involvement will largely depend on the possibilities to produce fuel resources in the country.

The volume of national coal production can be increased substantially. With the investments available and with the demand for coal, its production can reach $450-500 \mathrm{mln}$ t/year or 270$300 \mathrm{mln}$ tce by 2020 [17] compared with the current production level of $300 \mathrm{mln}$ t or $180 \mathrm{mln}$ tce annually.

It is not easy to increase the volumes of gas production. Aside from the need to invest huge sums of money in the development of new gas production areas it is necessary to consider time lag. For example, it will take 12-13 years at best for the volume of gas production on Yamal to reach 240-250 bln $\mathrm{m}^{3}$ /year (this is a maximum volume) from scratch.

In 2006 the country produced 656-bln $\mathrm{m}^{3}$ of gas. Based on the estimates of the Energy Systems Institute, Irkutsk, Russia, gas production level in Russia in 2020 will be not exceed $680 \mathrm{bln} \mathrm{m}^{3}$. This is on the assumption that:

- $\quad$ gas production on Yamal will start in 2010 and will then grow and reach the level of 240 bln $\mathrm{m}^{3}$ /year in 2020;

- gas production at the Shtokmanovskoye field will start in 2011-2012 reaching the maximum annual production $60-80$ bln $^{3}$ /year in 2020-2025;

- total volume of gas production in other new areas (the Sakhalin Island Shelf, Irkutsk region, the Sakha republic (Yakutia) and other regions) will reach 40-bln $\mathrm{m}^{3}$ in 2010 and 60-80 bln m³ /year in 2015-2020.

Taking into account the above, the potential volumes of gas and coal involvement in the fuel mix of Russia, and the potential volumes of their use for production of electricity and centralized heat at co-generation plants have been compared up to 2020. The model-based studies took into consideration that all gas and coal involved in the fuel mix is consumed for two purposes:

- production of electricity and centralized heat;

- use by all other categories of consumers (industry, population, housing and public utilities, etc.).

The results of the comparison are presented in Table 6.

Separation of coal and gas demand for production of electricity and heat, and for other needs allows estimation of the extent to which the shares of these energy resources will be redistributed in the future. For example the demand for fuel at thermal power plants in 2020 can be met owing to 290-mln tce of gas that can be supplied by the gas industry and up to 210-mln tce of coal that can be supplied by the coal industry. 


\begin{tabular}{|c|c|}
\hline \multicolumn{2}{|c|}{ Natural gas, $\mathbf{b} \boldsymbol{l n} \mathbf{m}^{\mathbf{3}}$} \\
\hline Potential production & up to 680 \\
\hline Own needs of the industry & 60 \\
\hline Possible import & 60 \\
\hline Possible export & 170 (except for electricity and heat production at TPP) \\
\hline Domestic demand & up to 250 \\
\hline Reserve* & up to 290 \\
\hline Reserve in mln tce & Coal, $\boldsymbol{m} \boldsymbol{l n} \boldsymbol{t}$ \\
\hline Potential production & up to 500 \\
\hline Possible import & 15 \\
\hline Possible export & 80 (except for the electricity and heat production \\
\hline Domestic demand & at TPP) \\
\hline Reserve* & up to 345 \\
\hline Reserve in mln tce & up to 210 \\
\hline
\end{tabular}

*Gas and coal volumes that can be used at Thermal Power Plants

Table 6. Comparison of Possible Coal and Gas Involvement in Fuel Mix of Russia and Volumes of use for Production of Electricity and Centralized Heat (2020)*

Thus, the prospective relationship between gas and coal use for production of electricity and centralized heat at cogeneration plants can make up $58 \%$ or $290 \mathrm{mln}$ tce of natural gas against $42 \%$ or $210 \mathrm{mln}$ tce of coal.

It should be noted that in 2006 the gas share neared $70 \%$. Besides, there was fuel oil in the fuel mix in 2006. For 2020 fuel oil (as a basic fuel) was not considered in the fuel mix: by that time this kind of fuel should be only used as an emergency reserve and process fuel (for example ignition of steam generators at cogeneration plants).

In summary, the gas share at thermal power plants of Russia, despite a sharp gas price rise (from $50 \$ / 1000 \mathrm{~m}^{3}$ in 2007 to $170 \$ / 1000 \mathrm{~m}^{3}$ in 2020), can be decreased only $11-12 \%$ in favor of increase in the coal share, which to some extent will enable one to mitigate the cost rise of the electricity and centralized heat produced at TPPs in the natural gas demand zone. The above can be real if future coal generation is based on clean coal, modern technologies.

\section{China: Future of natural gas coal consumption in Beijing, Guangdong and Shanghai - An assessment utilizing MARKAL}

There are many uncertainties regarding the future level of natural gas consumption in China. Using an economic optimization model MARKAL [21], drivers including the level of sulphur dioxide emissions constraints set by the government, the cost of capital, the price and available supply of natural gas, and the rate of penetration of advanced technology on both the supply and demand sides are considered. The results show that setting strict rules for $\mathrm{SO}_{2}$ emissions will be instrumental in encouraging the use of natural gas, and may also cause some reduction in $\mathrm{CO}_{2}$ emissions. Conversely, the currently differentiated cost of capital for various sectors within the Chinese economy artificially boosts the economics of 
capital-intensive coal relative to natural gas. This suggests that financial reform could be a lever for encouraging increased gas use.

Traditionally, gas supplies have been delivered entirely within regional markets - usually with little geographical distance between the source of gas and its ultimate combustion. However, a significant and growing fraction of world gas is traded longer distances via pipeline and, increasingly, as LNG. The rising role of LNG is interconnecting gas markets such that a single global market is emerging [18].

Within this increasingly integrated gas market, the role of China remains highly uncertain. Today, China's share of the global gas market is tiny; with a natural gas market that is smaller than California's [19], but the future demand for natural gas in China is potentially enormous. With an average gross domestic product (GDP) growth of $9.6 \%$ for the last twenty years (China National Bureau of Statistics, 2006) [20] and no signs of slowing down, China's demand for energy commodities-coal and oil, notably-has been expanding rapidly. With appropriate policies, natural gas could also grow rapidly.

Potential drivers for increased natural gas demand within the Chinese energy system are now examined where three regions are focused on: Beijing, Shanghai and Guangdong. This regional model reflects that natural gas sourcing and the downstream natural gas market vary greatly by region due to climatic and geographical barriers. For example, Guangdong receives no pipeline gas and is dependent on LNG imports (at present from Australia), while domestic pipelines principally supply Beijing's and Shanghai's gas demands. The major off-takers for the gas differ between regions as well. In Shanghai, for example, the industrial sector consumes almost all of the gas, while peaking power plants are major off-takers in Guangdong. The regional organization reflects the political realities of decision-making in China. While there are national policies on energy in China, most decisions that affect the usage of natural gas are made at the provincial and local level and driven by the economics and consumption patterns of each locale. A regional focus is therefore useful to model the nuances unique to each area.

In analyzing the energy systems of Beijing, Guangdong, and Shanghai, three separate, regional MARKAL models are used. Given a projected level of total energy demand services, each MARKAL model solves for a least cost optimal solution) [21] over the course of twenty years (2000-2020), utilizing a menu of technologies that is provided as an input for the models. The specific types of energy and emissions control technology are characterized by performance and cost parameters. The model solves by selecting a combination of technologies that minimizes the total system cost and meets the estimated energy demand. The goal is not necessarily to produce a firm prediction of future gas use, since key input assumptions, such as the level of demand services, are highly uncertain. Rather, such models are particularly well suited to reveal how sensitive natural gas demand is to key factors.

Some of the major factors that are likely to affect future demand for gas have been identified to include:

- $\quad$ Rate at which more efficient end-use technology is made available

- Stringency of local and regional environmental constraints

- Financial reforms that affect the cost of capital for different sectors of the economy (i.e., power, industry, residential, commercial, transportation)

- Pricing and availability of gas. 
The most important drivers (apart from polices that directly influence the price of natural gas relative to other fuels) that affect the consumption of natural gas are the implementation of $\mathrm{SO}_{2}$ controls in the system and financial reforms. For very tight limits on $\mathrm{SO}_{2}$ emissions, a switch to natural gas in the power and industrial sectors becomes the economically optimal alternative to other fossil fuels in many cases. When the rise in gas demand is in the industrial sector, this gas displaces oil. In the power sector, where gas competes with coal, it is much harder for gas to gain a substantial share of the market. A side benefit to $\mathrm{SO}_{2}$ emissions reduction policies is a corresponding decline in $\mathrm{CO}_{2}$ emissions of the order of 60 million tons $\mathrm{CO}_{2}$ for some locales (equivalent to about a quarter of the entire stock of Clean Development Mechanism projects in China) (UNEP, 2007) $)^{1}$.

This suggests that a leverage point for governments in developing countries like China to start addressing global concerns about climate change is through regulation of local pollutants that yield visible and immediate benefits while also fortuitously limiting growth of $\mathrm{CO}_{2}$.

As for the effects of financial policies on energy consumption, with differentiation of the cost of capital by sector as occurs in China today, the consumption of coal is particularly favored. The power sector has access to cheaper capital than other sectors within the economy, providing an incentive to build power plants with a high ratio of capital to operating costs. This arrangement favors large coal facilities, which are expensive to build and cheap to operate, over natural gas plants, which are cheap to build but expensive to operate because of the higher price of gas. While the situation is now changing due to financial reforms, it may help explain why gas has had a particularly difficult time making inroads in the power sector. This also suggests that financial reforms could have a big impact on the country's $\mathrm{CO}_{2}$ emissions.

\subsection{Methodology}

The pivotal policy driver for each of the regional model scenarios is the implementation of sulphur dioxide $\left(\mathrm{SO}_{2}\right)$ constraints upon the energy system. $\mathrm{SO}_{2}$ is used as a proxy for the full range of local pollutants -- future studies might model other pollutants more directly. Currently, data for $\mathrm{SO}_{2}$ is the most complete and accurate of all the pollutants that are monitored in China (compared to data for $\mathrm{NO}_{x}, \mathrm{PM} 10, \mathrm{PM} 2.5, \mathrm{CO}_{2}$ ).

To examine the influence of $\mathrm{SO}_{2}$ constraints, three "core" scenarios were developed. In the base case reference scenario (R), it is assumed that no changes are made to the status quo. The model operates on a least cost optimization paradigm so that it solves for the most economically favorable solution. In this situation, coal is expected to out-compete gas in all sectors due to the lower fuel cost. Some emissions control programs are already in place on the national and regional levels; the reference case scenario only includes policies that are currently implemented, as well as highly likely extensions of those policies. From this starting point, there are two main scenario developments.

\footnotetext{
${ }^{1}$ UNEP Riso Centre, Capacity Development for the Clean Development Mechanism, http://www.cdmpipeline.org
} 
Scenario " $\mathrm{P}$ " is the case in which the output $\mathrm{SO}_{2}$ emissions are reduced by $40 \%$ from the reference case and is defined as the "plausible" scenario. This scenario tests the system response if $\mathrm{SO}_{2}$ emissions are capped at a level $40 \%$ below what is currently expected in the status quo.

Scenario " $\mathrm{Ag}$ " is the case in which $\mathrm{SO}_{2}$ emissions are reduced by $75 \%$ from the baseline. This is defined as the "aggressive" scenario and is less likely to represent the future than scenario " $\mathrm{P}$ ", but is not entirely out of the question.

Having defined the core $\mathrm{SO}_{2}$ scenarios, the "More Gas" scenarios ("M") were developed. The goal of these extensions is to find out how the system would react to sensitivity parameters with a plausible $\mathrm{SO}_{2}$ constraint and more gas supply available to the region (such as might be available from a successful effort to develop international pipelines and price gas favorably). With the "MoreGas" scenarios, it is possible to determine the relative effects of gas availability and pricing as compared with the other drivers in the model.

Within each of the core scenarios, how gas demand would vary with two other factors was studied. First, the rate at which efficient, advanced end-use technology is allowed to enter the market (the "Fast" scenarios) was changed. Second, how specifying different costs of capital for each of the sectors would impact on consumption patterns (the "Diffcost" scenarios) was investigated. The factors were also combined with each other.

In all, twelve scenarios were studied. These scenarios allow four broad hypotheses to be investigate, namely:

1. Policies that constrain total $\mathrm{SO}_{2}$ emissions from the entire system lead to increased natural gas consumption.

2. The rate of technological diffusion significantly influences the amount of natural gas consumed within the system.

3. Varying the cost of capital for different sectors has an effect on energy consumption patterns.

4. Gas prices and the availability of gas are important factors in determining which sector consumes what volume of natural gas.

\subsection{Results}

\subsubsection{Constraints on $\mathrm{SO}_{2}$ emissions}

Figure 8 shows projections of natural gas consumption for the reference $(\mathrm{R})$, the plausible $(\mathrm{P}$, $40 \%$ reduction in emissions), and the aggressive ( $\mathrm{Ag}$, 75\% reduction) scenarios from 2000 to 2020 in all three areas. The estimates for consumption vary widely depending on which $\mathrm{SO}_{2}$ constraint is implemented in the system. From 2000 to 2020 in the reference base case, natural gas consumption increases by about six times in Beijing and fifty times in Shanghai. Guangdong goes from zero gas consumption to around $5 \mathrm{bcm}$. The natural gas consumed in 2020 in the aggressive scenario for all three regions is close to $50 \mathrm{bcm}$ greater than the amount consumed in the reference scenario. These results suggest that a tighter $\mathrm{SO}_{2}$ constraint leads to a higher gas demand. 


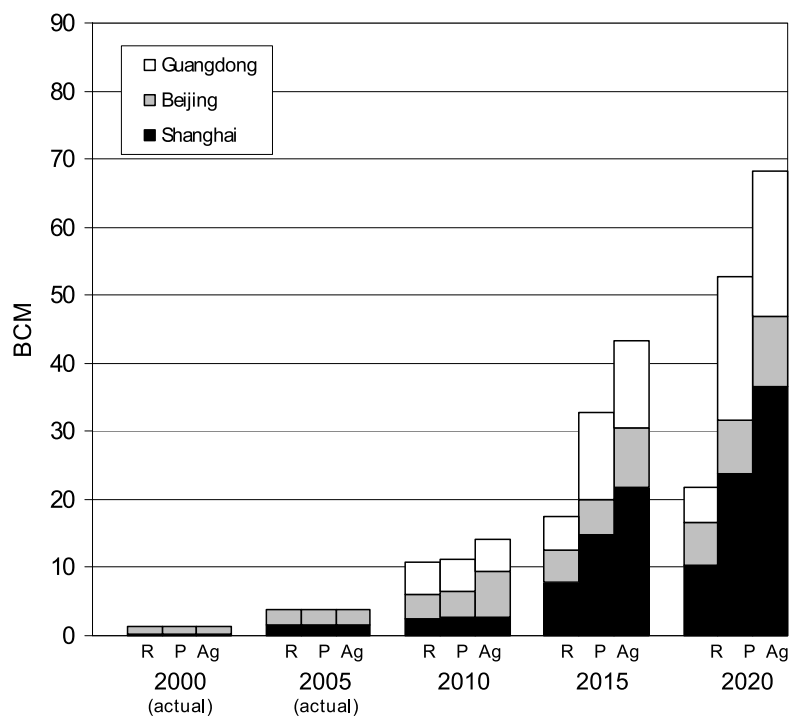

Fig. 8. Natural gas consumption for all study areas: Comparison of results for reference and $\mathrm{SO}_{2}$ constrained scenarios

\subsubsection{Effects of differing costs of capital across sectors}

This section examines effect of varying costs of capital reflective of the historical reality of the Chinese financial system (P Diffcost) and compares it with behavior under a uniform cost of capital across all sectors. For reference runs, what has been done many times in other models is replicated, which is to assume that there is a uniform discount rate across all sectors $(10 \%)$ reflecting the assumption that the cost of capital is uniform. For the scenarios that vary cost of capital, however, the actual differentiated discount rate system under which the Chinese economy has been operating is simulated by assigning different lending rates for each sector in MARKAL [22]. These different discount rates should lead to a significantly different energy system.

Coal consumption in the modest environmental constraints scenario is higher in the case of differentiated costs of capital between sectors. With their high investment and low O\&M costs, coal-fired power plants benefit disproportionately from the low cost of capital for the power sector, while gas plants with their low fixed and high O\&M costs are comparatively disadvantaged.

Taking a look at Guangdong, coal consumption is a dramatic 88\% higher under differentiated costs of capital, with natural gas consumption lower by about $40 \%$ (Figure 9). Advanced coal plants with pollution control equipment (FGD, ESP) are built at the expense of LNG-fired power plants. In fact, the situation on the ground is already evolving in this direction due to rising LNG prices in recent years.

Next, what affect that some of the scenarios may have on $\mathrm{CO}_{2}$ emissions is examined. In particular, the hypothesis that limits on $\mathrm{SO}_{2}$ could yield some reduction in $\mathrm{CO}_{2}$ due to greater use of natural gas is considered. $\mathrm{CO}_{2}$ emissions reductions in response to $\mathrm{SO}_{2}$ limits are most 
apparent in Guangdong. In the case of the aggressive scenario, about 99 million tons less of coal would be used in 2020 compared to the reference case. Figure 10 explains the carbon consequences of this fuel switch for Guangdong. Imposing a 75\% emissions cap on the $\mathrm{SO} 2$ emissions can avert about 57 million tons of carbon dioxide emissions. For comparison, 50 million tons is about a quarter of the $\mathrm{CO}_{2}$ saved by the entire stock of Clean Development Mechanisms (CDM) projects in China in 2006. It is also a quarter of Europe's Kyoto commitment [23]. While in absolute numbers these savings alone will not alter the global trajectory of climate change, they do suggest new ways of thinking about the climate issue, especially with regard to how to bring developing countries to the climate negotiation table.

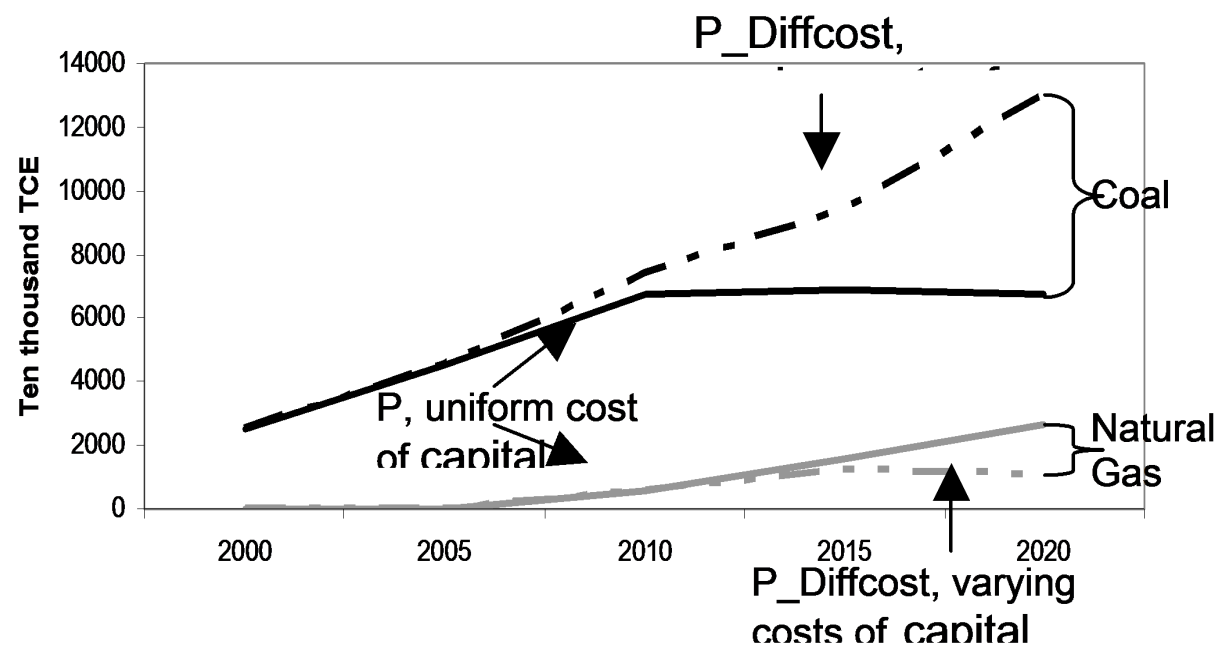

Fig. 9. Coal and Natural Gas Consumption in the Guangdong (Power Sector) 


\subsection{Implications for $\mathrm{CO}_{2}$}

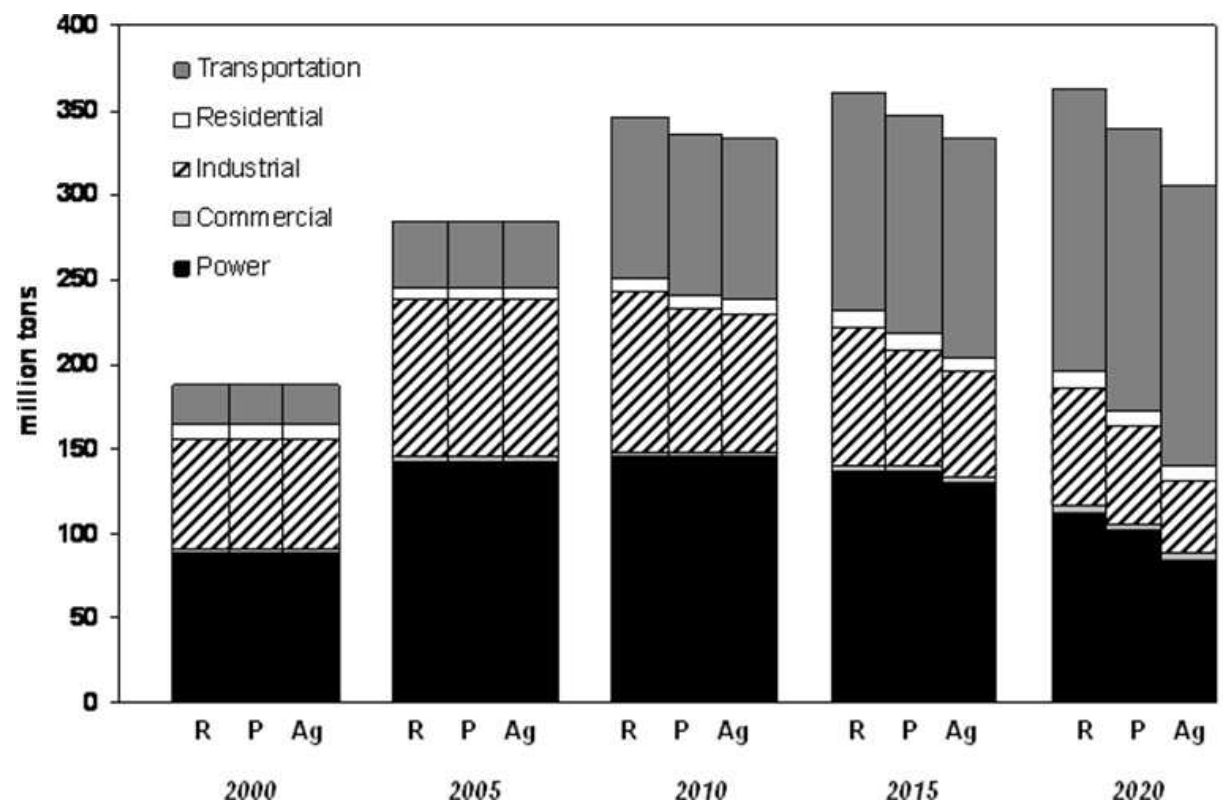

Top to bottom: Transportation; Residential; Industrial; Commercial; Power

Fig. 10. $\mathrm{CO}_{2}$ Emissions from Guangdong in the Reference, Plausible, and Aggressive Scenarios 


\subsection{Key findings}

There are five key findings on competitiveness of natural gas in China over the next two decades:

1. China is a supply-constrained environment for natural gas. Growth in gas demand in China could lead to a surge of natural gas imports, as demand is likely to far outstrip domestic supplies in certain parts of the country. This supply constraint provides an impetus for the Chinese government to seek out new supplies, such as a large international pipeline from Russia, Kazakhstan, or Turkmenistan, and more LNG regasification terminals. It should be noted, however, that such international supplies (especially via pipelines) are often challenging and time-consuming to realize.

2. Gas demand is highly dependent on financial policies. The current Chinese financial system provides extremely low costs of capital for the power sector. This makes the construction of capital-intensive coal-fired power plants especially attractive. Because coal and natural gas are in direct competition as the fuel source in most cases, this diminishes the opportunity for more natural gas combined cycle plants to be built. In Guangdong, for example, the MARKAL model would predict almost $50 \%$ lower coal consumption by 2020 if a $10 \%$ discount rate were applied to all sectors. While policies related to the banking system do not usually factor into considerations for planning an energy system, the study shows that this is an important aspect to consider in creating the right incentives for a sustainable energy plan.

3. The industrial sector can in some cases be more attractive for fuel switching than the power sector. The study found that looking outside of the power sector for fuel switching opportunities could prove to be a cost effective option. According to the model, a switch from coal to natural gas boilers would be cheaper than forcing a switch in power plants in the case of Shanghai where the industrial sector is currently dependent on inefficient coal boilers. Replacing an inefficient coal boiler requires much less upfront capital than converting a power plant from coal to natural gas. When there are enough boilers in the industrial sector to make a difference in emissions, this is an especially attractive alternative.

4. The fuel mix for electricity generation is unlikely to change dramatically. In all of the scenarios that were tested in the model, coal remains the dominant fuel in the energy mix. Coal is simply too cheap and abundant to leave unused (China has the world's third largest coal reserves). Aggressive sulfur reductions do shift the electricity mix somewhat towards a greater role for natural gas, but sulfur reductions can often be met more cheaply through fuel shifts in the industrial sector and by installing end-of-pipe solutions on coal plants.

5. Non-climate policies could have a large impact on carbon emissions. While China is unlikely to accept binding carbon dioxide emissions reductions targets in the near future, very large $\mathrm{CO}_{2}$ reductions might be realized as a side benefit from other policies enacted for reasons other than climate concerns. For example, in the case of China, a cap on $\mathrm{SO}_{2}$ emissions could have a significant effect on $\mathrm{CO}_{2}$ emissions by promoting the use of cleaner burning fuels and more advanced technology. An $\mathrm{SO}_{2}$ policy might be more palatable to the Chinese government than explicit $\mathrm{CO}_{2}$ regulation because it addresses immediate local concerns about air quality and health that directly affects its citizens. Such issues are much more likely to gain traction and spur change in the near term. 


\section{LNG in South America: Markets, prices and security of supply}

Markets, prices and security of supply of LNG in South America is now reviewed. Latin America has been in recent years one of the most intensive regions for natural gas and electricity development [24]. The region is very hydropower dependent (about $57 \%$ of the region's installed capacity is hydro) and the need to diversify away from heavy investments in hydropower and oil is driving many South American countries to promote use of natural gas, especially for power generation. Examples of these developments are in Brazil, Chile and Colombia. Countries of the region have great diversity in size, electrical installed capacity, electrical power demand, and electrical transmission/natural gas network characteristics (level of meshing and geographical extension). Figure 11 shows the share of hydro and thermal power and the installed capacity in some countries of the region (2003 data).

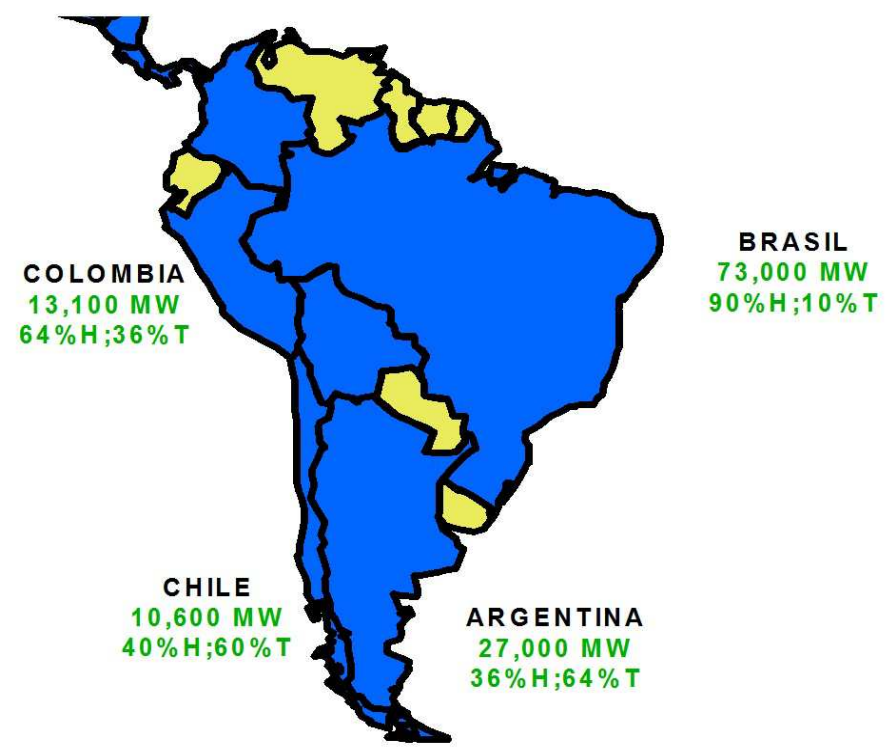

Fig. 11. South American Electricity Markets

Economic reforms have opened important sectors to private investors that were previously reserved to the State. This reform boosted the development of an infrastructure of electricity and natural gas pipelines in the region, both in each country separately and in cross-border electricity-gas interconnections.

The introduction of natural gas (NG) in the energy matrix of the countries took place in a more aggressive manner at the end of the 1990s, with construction of cross-border gas pipelines (Bolivia-Brazil, Argentina-Chile, etc) and the development of local gas production fields [24]. NG consumption for industrial and automotive use grew at quite significant rates and, in the electrical sector, the installation of gas-fired thermal generation also increased fast, representing the biggest potential market for the NG sector. Figure 12 presents an outlook of the potential demand and current gas reserves in the region. 


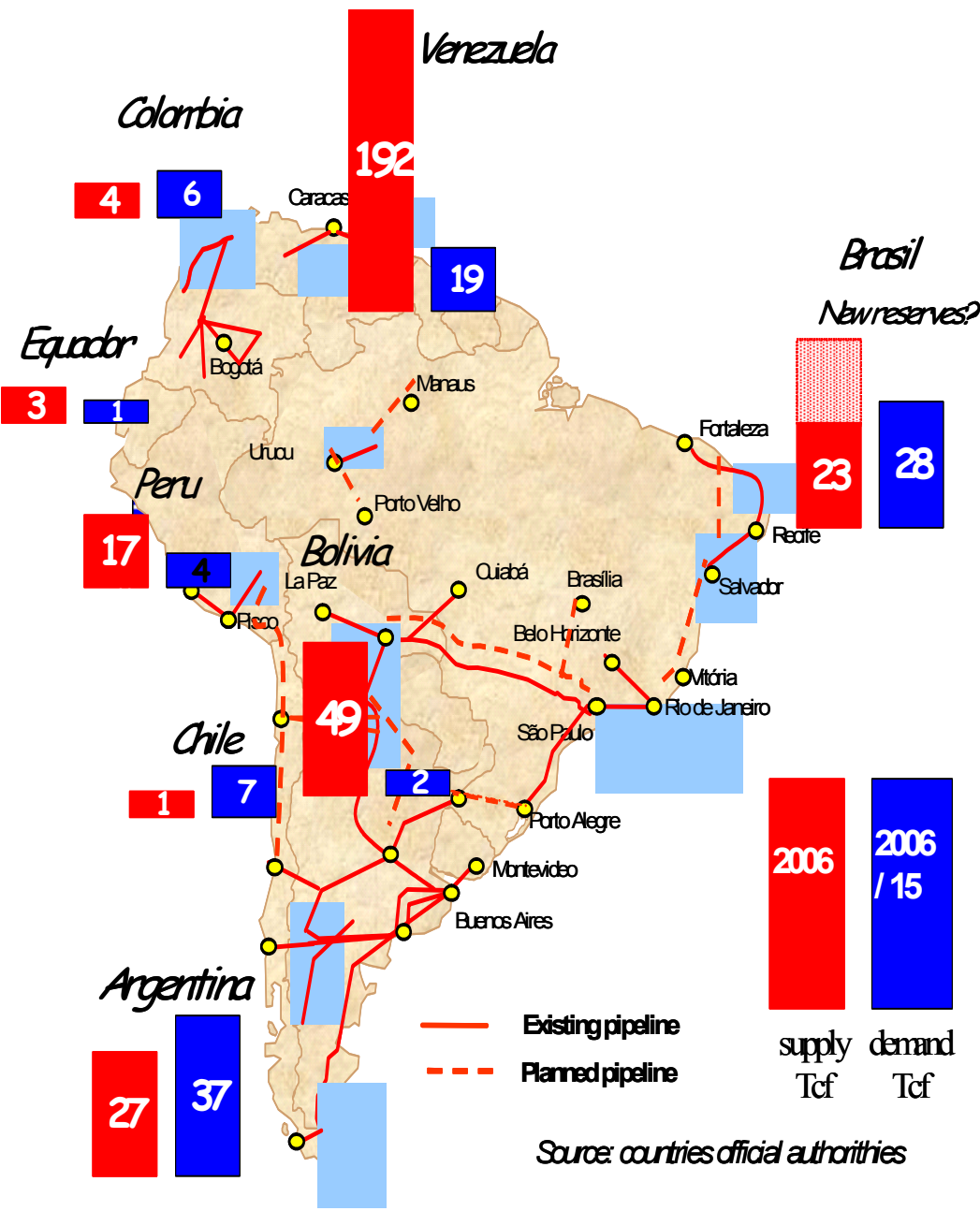

Fig. 12. Outlook of Potential Demand and Current Natural Gas Reserves in the South America Region.

While the "non-power" consumption of NG is practically constant (firm), gas consumption for thermal power plants is variable and strongly dependent on hydrological conditions. Hydro plants are able, during most of the time, to displace thermal energy production, which are then operated in complementation mode. This is achieved through hydrothermal coordination [25].

Over the period 2004-2008, Chile and Brazil decided to implement re-gasification plants to start importing LNG from 2009. Motivation for the two countries is quite similar: (i) to diversify the gas supply for the country (in case of Chile, to diversify from Argentina and in case of Brazil to diversify from Bolivia) and (ii) to create a flexible supply able to accommodate the use of gas to power generation. 


\subsection{LNG in South America: Markets, prices and security of supply}

\subsubsection{Why LNG?}

There are three main drivers behind LNG import and export in South America.

1. Gas imbalances: there are countries or sub regions with gas surpluses and others with deficits. Brazil, for example, has a growing potential natural gas market and still not enough gas production.

2. Security: in Brazil and Chile imports from neighboring countries have proven to be unreliable. and further dependence on supply from a single country is deemed to be undesirable.

3. Flexibility of gas supply: because of the hydro predominance in the region, gas-fired dispatch is very much volatile and flexibility is an attractive attribute.

\subsubsection{The markets}

LNG in South America is divided into importing countries with LNG re-gasification plants under construction (Brazil \& Chile), candidate importing countries (Argentina, Uruguay) and candidate exporting countries (Peru, Venezuela and Brazil in the future).

This means that LNG in South America is categorized into Brazil and Chile as importers. Figure 13 shows the LNG terminals. These countries are analyzed further.

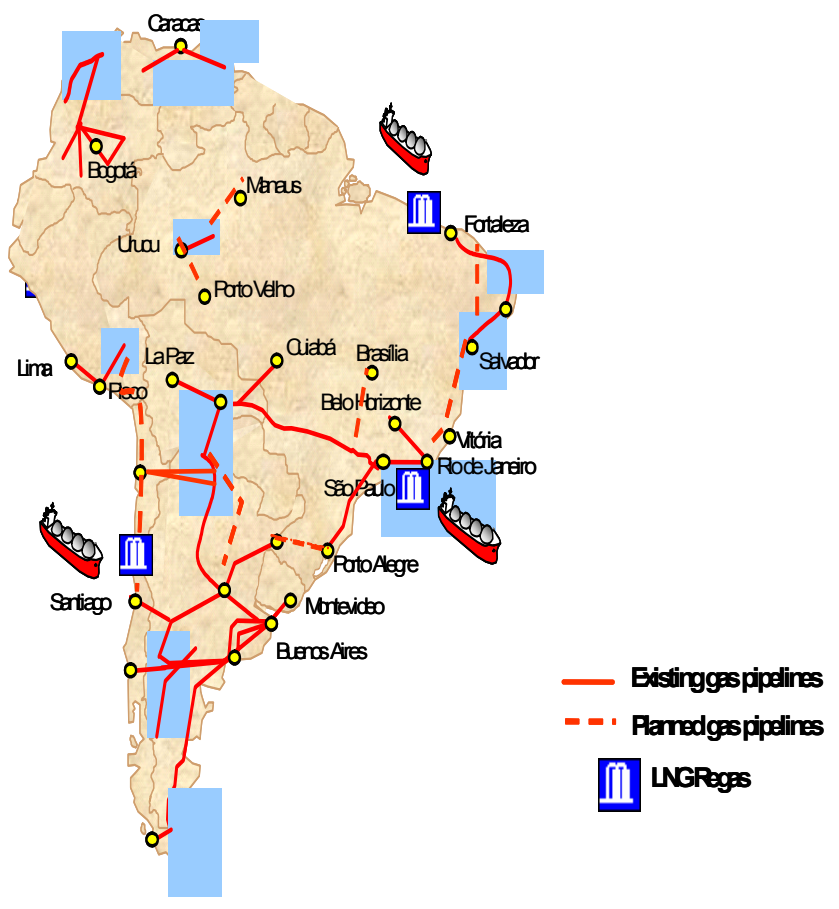

Fig. 13. South America LNG terminals 


\subsubsection{The prices}

The introduction of LNG will have several implications for the region's gas and energy markets, particularly in price benchmarks, energy security, and pipeline infrastructure.

LNG has an opportunity cost. Imported LNG could be more expensive than any regional gas supply and is likely to set a new price benchmark in almost all markets into which it is introduced. As LNG becomes more prominent in the energy mix, its link to global prices will create an inexorable pull on gas prices in previously isolated South American markets. LNG import prices in Latin America will also depend crucially on the timing of the different LNG projects.

\subsubsection{The security of supply}

The first reason for importing or exporting LNG is related to the region's natural gas balance: there are countries or sub regions with gas surpluses and others with deficits. The second reason is geopolitical and is related to energy security and the diversification of natural gas supplies and markets.

\subsection{Main challenges for LNG in Chile}

Chile has no significant local gas supply resources. The existing ones are located in the Southern part of the country, about $3,000 \mathrm{~km}$ away from the main demand centers. Chile started to import gas from Argentina in 1997. The Argentinean gas is responsible for the development of the Chilean gas industry and imports were responsible until 2004 for more than $70 \%$ of the country's gas supply, which is mostly concentrated in the central part of the country. The northern part of the country depends entirely on Argentina for their gas supply.

However, as discussed in [26], since 2004 Argentina has struggled to meet its own domestic gas needs and has started cutting exports to Chile. The total annual exports to Chile have been falling since 2005 and cuts started to be frequent and recently (2007) have reached as high as 95 percent of committed volumes on several occasions

\subsection{Main challenges for LNG in Brazil}

\subsubsection{Natural gas market in Brazil}

Ingress of NG in the Brazil energy matrix took place in a more aggressive manner at the end of the 1990s, with construction of the Bolivia-Brazil gas pipeline and development of local production fields. NG consumption for industrial and automotive use grew at quite significant rates (induced by tax benefit policies, by increase in supply and by prices) and, in the electrical sector, the installed gas thermal generation capacity also had a fast growth, so that in Brazil it accounts today for some $8000 \mathrm{MW}$. The question of natural gas supply for thermal generation has been the object of concern by the authorities ever since the conception of the new model for the Electrical Sector [27]. A recent (2006) "dispatch test" performed by Aneel (power sector regulator) in the gas thermal power plants disclosed that such concern is actually legitimate, because about $50 \%$ of the tested capacity in the South/ Southeast-Center West Regions did not manage to produce energy due to fuel deficiency. 


\subsubsection{The business model: LNG flexible supply}

The introduction of LNG is observed with interest by the electrical sector, for three main reasons: (i) to diversify gas supply sources, (ii) a contract market with shorter ranges and greater flexibility, and (iii) it is possible to build thermoelectric plants located relatively close to the major LNG delivery ports, thus avoiding investment (fixed costs) in gas pipelines.

In this manner, the final cost to the consumer of thermal energy produced from LNG may become more attractive. This is because the flexible supply of gas provided by LNG permits thermal power plants to be operated in the mode of complementing hydroelectric production and, therefore, fossil fuel is saved. As discussed in [28], the final consequence of this operation is the reduction of energy cost to the consumer ${ }^{2}$. Petrobras has announced its intention of contracting LNG to supply the Brazilian market in a flexible manner.

\subsubsection{Challenges for LNG supply}

LNG has one important characteristic: its price (as a commodity) strongly depends on how much in advance its order is placed. A LNG order placed one year in advance can normally have a fixed price, since the vendor has the possibility of contracting adequate hedges against the oscillations of the strongly uncertain and volatile international prices. On the other hand, a LNG order placed just a few weeks in advance has a price above that of usual references, associated to the opportunity cost of displacing this gas with respect to its destination market, and increased by an "urgency rate".

\subsubsection{Virtual gas storage: gas stored in hydro reservoirs}

The expectation of a LNG order for gas to be used in thermal dispatch may be frustrated by the occurrence of a more favorable hydrology than that expected. In this case, the requested natural gas would not be needed after the arrival of the liquefied gas carrier ships at the regasification stations.

\subsection{Virtual gas storage and smart electricity-gas swaps}

The introduction of flexible LNG supplies in the region can bring up several opportunities to integrate the electricity and gas markets in the region. This is because energy swaps with LNG are much more economical than the proposed point-to-point pipelines. An example of gas-electricity integration is the so-called "gas exports from Brazil to Chile without gas or pipelines". Essentially, Chile purchases $2000 \mathrm{MW}$ of electricity from Brazil, for delivery to Argentina (via the Brazil-Argentina DC link). The power from Brazil now displaces 2000 MW of gas-fired thermal generation in Argentina, which frees up $10 \mathrm{~mm}^{3} /$ day of natural gas supply, which is (finally) shipped to Chile.

\footnotetext{
${ }^{2}$ Thermal insertion in Brazil took place based on contracts for supply of inflexible gas, with 'take or pay' and 'ship or pay' clauses, which correspond to fixed payments, respectively to gas producer and to transporter. This way, the benefit of the operation and of the hydro-thermal synergy is not exploited, and the final cost of this technology becomes higher.
} 
Another example is the use of LNG against the proposed "Southern Gas Pipeline", from Venezuela to Brazil and Argentina.

In summary, the primary challenge for South American countries is to ensure sufficient capacity and investment to serve reliably their growing economies. The region has emerged as one of the most dynamic areas for natural gas and electricity developments. More recently, LNG has emerged as an attractive option. However, South America is a latecomer to the LNG business. Other regions and countries have already incorporated this external natural gas supply source in their portfolios for many years. An example of gas-electricity integration is the so-called "gas exports from Brazil to Chile without gas or pipelines". Essentially, Chile would purchase $2000 \mathrm{MW}$ of electricity from Brazil, for delivery to Argentina (via the existing 2,000 MW Brazil-Argentina DC link). The power from Brazil would displace $2000 \mathrm{MW}$ of gas-fired thermal generation in Argentina, which would free up $10 \mathrm{~mm}^{3}$ / day of natural gas supply, which would be (finally) shipped to Chile.

\section{Natural gas market dynamics and infrastructure development in South East Europe}

The status and outlook of the market dynamics and its related infrastructure in the South East Europe (SEE) is now discussed [29-32]. An important emphasis is given in the actual coalitions that will assist in the faster and more robust development of the gas sector in SEE, the existing infrastructure, the future projects that are under development or under study and the regulation that is needed in order to guide the above. The ultimate goal of these developments is the creation of a common financial market in the SEE region. Some of the most sensitive factors that have to be taken into consideration to smoothly accomplish the common market between the countries are also discussed.

SEE, during the last 5 years has demonstrated significant potential for development in the field of energy. More specifically, important projects and studies both in the electricity and gas sector have taken place. Since 2005, strategic developments in the sectors have entered a significant period where infrastructure and regulatory decisions from the SEE countries will define the energy map for the years to come.

\subsection{Context and status}

\subsubsection{Common market concept - The gas forum in Istanbul}

The countries of SEE are characterized by a low-level gas penetration. The use of power for heating is widespread in many of the region's urban areas. This has been identified as a problem in the "Framework for Development of Energy Trade in South East Europe " as power is a relatively inefficient means of providing heat, and the use of power for heat in South East Europe exacerbates energy affordability problems. From an environmental perspective, substituting gas for power for purposes of heating would result in lower greenhouse gas emissions given that the dominant form of power generation in the region is and will continue to be lignite based.

One obstacle to increased gas penetration is lack of a gas market in the region. The prevailing Russian gas monopoly has implications both for gas pricing and security of supply. Introducing competition to Russian gas through development of a gas market in the 
region would bring both price and security benefits. There is then scope for increased competition / diversification through transporting of Caspian gas across Turkey to SEE.

Recognizing the above needs, an Energy Community Treaty was created to develop a regional gas market. This Treaty is organized by the European Commission and basically requires that SEE countries undertake gas sector reforms through development of regulatory frameworks and industry unbundling with a view to increased gasification in each state and establish an integrated regional energy market and progressively ensure its integration into the European Community's Internal Energy Market.

The Istanbul Gas Forum was established to support development of a SEE Gas market and follow the implementation of the Treaty. The Gas Forum in Istanbul is to the countries of SEE what the European Gas Regulatory Forum in Madrid is to the EU countries. The aim is to facilitate development of a regional gas market and bring Caspian gas into the Balkans region, the key element being to establish a surer supply of gas for the Union. This is not only because Europe will have access to new sources from the east but because the new market will operate according to the EU's own rules reflected in the newly created energy community in SEE.

The Gas Forum in Istanbul comprises representatives of the European Commission, governments, regulators and transmission system operators of the countries of SEE, the Council of European Energy Regulators (CEER), the European Transmission System Operators (ETSO), representatives of donors, gas producing companies, and consumers. The Forum is co-chaired by the European Commission and a representative of the president in office.

The Gas Forum has created a regional plan with the following objectives:

- To implement national gas market reform in all signatory countries

- To implement international best practice in the wholesale gas markets and to facilitate cross-border trade

- To create regional and national gas markets, in part to reduce the environmental impact of existing thermal plants; and,

- To secure supplies for the region and the EU through the creation of a seamless integrated market between Vienna and Ankara.

\subsubsection{Actual situation of the gas market in SEE}

The countries of SEE are neither major natural gas producers nor consumers. Although the region does hold some fossil fuel deposits, these resources are not significant on a world scale. The gas market in the region is relatively underdeveloped considered as a whole, but this masks wide difference between the Eastern Balkans through into Turkey, and the Western Balkans through into Albania. In the Eastern Balkans and Turkey, gas use is either mature (Romania) or rapidly developing (Turkey and Bulgaria). In the Western Balkans, gas supply to Albania, Bosnia and Herzegovina, Croatia, FYROM, Montenegro, Serbia and UNMIK Kosovo is either underdeveloped or non-existent or has fallen into disuse (Montenegro and UNMIK have no gas infrastructure at all).

Natural gas is mainly used in industry and partly in power generation in the region (except in Bosnia and Herzegovina in which it is used in residential and commercial sectors and in Turkey in which it is used mostly for power generation). 
Most of the countries import natural gas only from Russia. Only Turkey has diversified their sources of supply, and only Romania, Croatia and Serbia have some domestic reserves.

In most Countries, postage stamp methodology is or is expected will be used for transmission. Tariffs are mostly determined and/or approved by Regulatory Authorities. However it is not yet clear whether such tariffs, as well as other features of third party access regimes in the region (with the exception of Romania) are suitable for the development of competition. In fact they are not used due to the lack of competitors.

While several pipelines physically link several countries, their transit rights are almost entirely attributed to long-term contracts for import from external sources. As a consequence, none of the countries has access to the other's market or facilities that may boost security of supply, like domestic production fields, storage plants and LNG terminals.

\subsubsection{Final goal: Creation of a financial common market similar to the NW Europe}

Firstly, improving the balance between energy supply and demand is crucial to improve and sustain economic development in SEE. This requires a strong legal commitment by the countries of the region towards market oriented reforms, regional integration and sustainable development, and investment security. This will offer significant advantages both in terms of improved utilization of existing supply and production capacities, but also in fostering more cooperation and integration in the region, which would result in economic growth, stability and investment.

Secondly, the security of supply of the European Union is based on diversifying supply of gas and in being politically able to counter threats to energy disruption in the European Union. By connecting this strategic area with the internal energy market, this will assist in assuring both the European Union's security of supply and that of the region.

The final goal is to achieve the fluidity level of the electricity and gas markets of NW Europe where many energy trading transactions occur each day promoting gas to gas competition and resulting to the lowest European gas prices in the wholesale gas markets such as those in UK, Holland and Belgium.

To achieve this goal the Energy Community Treaty has three operational parts:

i. The treaty will extend the application of the energy, environmental, renewable, competition and other parts of the acquis communautaire (legislation and rules decided at EU level). This will create a level playing field, though there will have to be credible, effective and policed transition dates.

ii. The treaty will create regional mechanisms that extend into the European Union to allow for deeper integration of local energy markets. This will for example mean enabling regulation allowing for accelerated infrastructure development, in particular for gas pipelines (especially new connections to the Caspian Sea and the Middle East).

iii. Given that the idea of a common energy market is central to the Energy Community, there is agreement to work toward common policies for external trade, mutual assistance and the removal of internal energy market barriers. 
The Energy Community Treaty provides that the states will:

- implement electricity and gas tariff reform plans;

- implement all necessary technical standards, such as grid codes, accounting systems and information exchange for the operation of the grid;

- implement effective third party access to infrastructure;

- create National Regulatory Authorities and transmission system operators;

- develop local solutions to pressing problems of regulation, energy poverty and social equity, and

- $\quad$ implement the gas and electricity directives.

\subsection{Actual infrastructure}

\subsubsection{Transmission, storage and distribution capacity}

The Natural Gas (NG) Transmission network is relatively underdeveloped in the region. The NG Transmission infrastructures are owned and operated by state companies.

Bulgaria, Croatia, Romania, Serbia and Hungary have underground storage with a total working Gas capacity of 7,500 mcm from which only Romania and Hungary have 6,000 mcm of storage working gas capacity. Turkey and Greece have LNG Terminals. Turkey has 2 LNG Terminals and Greece 1.

NG Distribution networks are relatively underdeveloped in the region. The distribution lines per capita index are significantly high in Croatia and Serbia. In all other Non-EU ECSEE Countries the distribution network is under fast development. Infrastructure in Hungary only is very well developed.

Sizeable total market is $47.5 \mathrm{bcm} /$ year in Non-EU ECSEE Countries and $103.4 \mathrm{bcm} /$ year in EU-ECSEE Countries (Italy, Hungary, Austria and Greece).

In the Non-EU ECSEE Countries, the weighted average share of gas in primary energy supply is $23.8 \%$, which is very close to that of EU Members average $(24 \%)$. Gas markets in Austria, Hungary and Italy feature high levels of per capita consumption and low expected growth rates; hence they can be regarded as mature markets. Among Non-EU ECSEE Countries the only relatively mature gas market in the region is Romania

Greek, Turkish, Serbian, Bulgarian and Croatian gas markets are expected to develop rapidly. In the remaining countries of the region gas consumption has either just started recently or is very little developed. Turkey and Romania consume $83 \%$ of the total consumption.

Natural Gas is mainly used in industry and partly in power generation in the Non-EU ECSEE and Greece. In more mature EU-ECSEE Countries consumption patterns are more mixed.

\subsubsection{Regulatory framework, market transaction and players}

Most of the countries in the region have opened theirs markets, and identifying at least some eligible threshold. 
All the countries in the region have their respective independent Regulators. Transmission System Operators (TSOs) and Distribution System Operators (DSOs) are in process of legal and managerial unbundling. Accounting unbundling is foreseen for almost all activities. Access to domestic pipelines is regulated in most of the countries in the region. However, as far as the transit network is concerned, access is in principle regulated in some countries of the region and is negotiated in others.

In most Non-EU-ECSEE Countries, postage stamp methodology is being or is expected to be used for transmission. Tariffs are mostly determined and/or approved by Regulatory Authorities. However, it is not yet clear whether such tariffs, as well as other features of Third Party Access regimes in Non-EU ECSEE countries and in Greece (with the exception of Romania), are suitable for the development of competition. In fact they are not used due to the lack of competitors.

\subsubsection{Actual technical problems for infrastructure development}

The inadequate gas infrastructure in all domains (transmission, distribution and storage) is based on the following:

- The domestic resources are limited (except Romania),

- No diversification of external supplies, including LNG,

- Non-EU ECSEE countries as well as Greece have no access to each other's markets or facilities that may boost security of supply, like domestic production fields, storage plants and LNG Terminals,

- The geology of the region where the major part of the territory in the region is covered by high mountain chains, and

- Poor experienced construction and manufacturer local companies in the gas industry (piping manufacturer, special machinery for construction etc.).

\subsection{Future development}

\subsubsection{Gas projects development}

The energy industry, represented by the International Association of Oil and Gas Producers (OGP) believes that the Caspian Region holds 6\% of the world's natural gas reserves, with $12,240 \mathrm{bcm}$, representing 178 years of gas supply at the current rate of production (148 $\mathrm{bcm} /$ year). Forecasts predict that production will double in 15 years. OGP also presented statistics and forecasts for Iran which possesses $27,500 \mathrm{bcm}$ of natural gas but which consumes slightly more than $85.5 \mathrm{bcm}$ annually which it produces. Together, Iran and Iraq could supply more than $100 \mathrm{bcm} /$ year to the export potential of the Caspian Region. Currently the gas production from the Caspian Region is between 80 and $100 \mathrm{bcm} /$ year. In comparison, the EU consumes approximately $500 \mathrm{bcm} /$ year, $55 \%$ of which is imported.

Infrastructure feasibility studies until now have dealt with four projects. The first is the Nabucco project linking Turkey with Austria via Bulgaria, Romania and Hungary. A second project is to link Bulgaria with Serbia, and a third, piloted by Edison Gas is to link Turkey with Italy passing through Greece but not Albania. In competition with this is a fourth project, piloted by the Swiss utility EGL with the intention of linking the Greek network with Italy, but this time via Albania. A fifth project, the "West Balkan connector" still in the 
study phase, will connect Greece with Slovenia via the FYROM, Serbia, Bosnia-Herzegovina and Croatia. All these projects will be examined by the World Bank and judged according to the benefits that they could offer the region

A recently announced project by the Russian Gas Giant Gazprom and ENI is the South Stream Pipeline. This pipeline will cross the Black Sea from the East (Russian Coast) to the West (Bulgarian Coast) bypassing Turkey and connect to the Bulgarian Gas Grid. From this grid it will be spit into two sub-streams: The south sub-stream will be connected to the gas grid and with use of the IGI Interconnector will bring Russian gas supplies to Italy and then to Europe. The north sub-stream will be routed to Austria via Serbia, Romania and Hungary. This last project will be in competition with the "Nabucco" project.

The List of the 10 major Gas Projects in SEE are indicated in Table 7:

\begin{tabular}{|c|c|c|c|c|c|c|}
\hline & $\begin{array}{c}\text { Planed/Proposed } \\
\text { Gas Routes }\end{array}$ & $\begin{array}{c}\text { Length } \\
(\mathbf{k m})\end{array}$ & $\begin{array}{l}\text { Capacity } \\
\text { (bcm/year) }\end{array}$ & Sponsor & $\begin{array}{l}\text { Cost } \\
(\text { mill) }\end{array}$ & Stage \\
\hline 1 & $\begin{array}{c}\text { South Caucasus } \\
\text { Pipeline }\end{array}$ & 960 & $7.1-22$ & BP-Statoil & $900 \$$ & $\begin{array}{c}\text { In } \\
\text { Operation }\end{array}$ \\
\hline 2 & $\begin{array}{l}\text { Turkey-Greece } \\
\text { Interconnector } \\
\text { (TGI) }\end{array}$ & 285 & $3.6-12$ & $\begin{array}{l}\text { Botas- } \\
\text { DEPA }\end{array}$ & $280 \$$ & $\begin{array}{c}\text { In } \\
\text { Operation }\end{array}$ \\
\hline 3 & $\begin{array}{l}\text { Greece-Italy } \\
\text { Interconnector } \\
\text { (IGI) }\end{array}$ & 804 & $8-12$ & $\begin{array}{l}\text { Edison- } \\
\text { DEPA }\end{array}$ & $1300 \$$ & $\begin{array}{l}\text { Advanced } \\
\text { Study } \\
(\exp 2011)\end{array}$ \\
\hline 4 & $\begin{array}{c}\text { Nabucco } \\
\text { (TR-BUL-ROM- } \\
\text { HUN-AUS) }\end{array}$ & 3400 & $25-30$ & $\begin{array}{l}\text { Botas- } \\
\text { Bulgargas } \\
\text {-MOL- } \\
\text { OMV }\end{array}$ & $4400 €$ & $\begin{array}{l}\text { Advanced } \\
\text { Study } \\
(\exp 2012)\end{array}$ \\
\hline 5 & $\begin{array}{l}\text { Hungary-Romania } \\
\text { Interconnector }\end{array}$ & 55 & $0.5-2$ & Trnasgaz & $20 \$$ & \\
\hline 6 & $\begin{array}{l}\text { Serbia-Bulgaria } \\
\text { Interconnector }\end{array}$ & 230 & 3 & $\begin{array}{c}\text { Bulgargaz } \\
\text {-NIS }\end{array}$ & & Study \\
\hline 7 & $\begin{array}{l}\text { Trans Adriatic (N) } \\
\text { (BUL-M-AL-IT) }\end{array}$ & & & EGL+ & & Study \\
\hline 8 & $\begin{array}{c}\text { Trans Adriatic (S) } \\
\text { (GR-AL-IT) }\end{array}$ & 570 & & EGL & & Study \\
\hline 9 & $\begin{array}{l}\text { Western Balcan } \\
\text { Corridor }\end{array}$ & & & $\begin{array}{l}\text { Relevant } \\
\text { Countries } \\
\text { TSO }\end{array}$ & & Study \\
\hline 10 & $\begin{array}{l}\text { South Stream } \\
\text { (RUS-BUL-GR- } \\
\text { SER-HUN-AUS }\end{array}$ & 900 & 30 & $\begin{array}{l}\text { Gazprom- } \\
\text { ENI }\end{array}$ & $1000 €$ & \\
\hline
\end{tabular}

Table 7. Major Projects in South East Europe 


\subsubsection{Regulation and liberalized market development}

Most benefits can only be achieved through a single common market, as most national markets in the region are too small.

Some of these benefits are:

- Negotiating for import supplies,

- Diversifying of gas sources,

- Ensuring security of supply through use of storage, interconnection and LNG facilities of each country,

- Exploiting economies of scale in gas transportation,

- Matching excess supply with excess demand markets in the short and long run, and

- Developing new long distance transmission infrastructure.

Consistently with the experience of the EU market opening according to the Directives 98/30/EC and 2003/55/EC, further research and regulatory effort should in particular address the following issues, with a view to ensure their necessary harmonization and their compatibility for a common market:

- Authorization and licensing regimes for existing and new transportation infrastructure,

- Technical standards and other obstacles to cross border exchanges, in comparison with the EASEE-gas process in the EU,

- Legal, fiscal and tariff barriers to cross border trade including destination clauses and other commercial restrictions,

- Independence and responsibilities of national market regulators,

- Stability, predictability and accountability of the regulatory framework,

- Regulated access to transmission, distribution and (at least in the medium term) storage and LNG facilities,

- Impact of existing and new long term contracts on competition in the region,

- Infrastructure capacity information and allocation criteria,

- Infrastructure financial viability under competitive conditions,

- Implementation of cost-reflective (preferably entry-exit) pricing mechanisms of transmission,

- Economically sound fair and non discriminatory public service obligation criteria,

- Legal and management unbundling of transmission and distribution operations,

- Criteria for release and availability of unused capacity,

- Promotion of gas consumption through environmentally consistent fiscal and regulatory policies,

- Increased cooperation and trade among ECSEE countries, and

- Promotion of measures to ensure security of supply on a non-discriminatory basis.

In summary, the actual status of the gas market in SEE has been reviewed. More specifically, emphasis on the actual coalition that assist the development of the gas market, the existing infrastructure, the future projects and the regulation that is currently set in place have been analyzed. The importance of existence of a common market to assist infrastructure development in the region has been identified. 
There is a fine geopolitical balance defined by US and Russian interests that are directly depicted from the projects under construction or study. Moreover, the provenance of funds from very different sources such as international organizations, countries, investment funds and utilities define an uneven order of priorities that might have a negative effect on overall development of the projects. Hence, there is a very delicate task submitted to all commissions, forums and boards that govern and supervise the process of development where a set of technical specifications and plans defining the projects have to be combined with a tense geopolitical situation.

\section{Conclusions}

1. As the electricity industry becomes more and more dependent on natural gas-fired generation, limits in the natural gas delivery system are becoming increasingly relevant to power system operation.

2. Dependence on gas imports to replace UK reserves for electric power generation is most likely to be both pricey and vulnerable to the loss of supply due to political instability.

3. With US and Canadian end-users adverse to long-term contracts for LNG there is risk that without committing to LNG it may not be available if needed in the future.

4. The gas share at thermal power plants of Russia, despite a sharp rise in gas price (from $50 \$ / 1000 \mathrm{~m}^{3}$ in 2007 to $170 \$ / 1000 \mathrm{~m}^{3}$ in 2020 ), can be decreased only $11-12 \%$ in favor of increase in the coal share, which to some extent will mitigate the rise in cost of electricity and centralized heat produced at Thermal Power Plants.

5. Growth in gas demand in China could lead to a surge of natural gas imports, as demand is likely to far outstrip domestic supplies in certain parts of the country. Fuel mix for electricity generation in China is unlikely to change dramatically. Non-climate policies could have a large impact on carbon emissions. Although China is unlikely to accept binding carbon dioxide emission reductions targets in near future, very large $\mathrm{CO}_{2}$ reductions might be realized as a side benefit from other policies enacted such as a cap on $\mathrm{SO}_{2}$ emissions.

6. There are opportunities for economic integration of regional gas-electricity markets in South America.

7. There are major projects under study and in operation for planned gas routes in South East Europe. The Caspian Region holds $6 \%$ of the world's natural gas reserves and production will double in the next 15 years. There is a fine geopolitical balance defined by United Sates and Russian interests.

\section{Acknowledgement}

Contributing Authors include Raymond Johnson, (Manager Portfolio Development, Southern California Edison, CA, USA), Michael Urbina and Zuyi Li (Illinois Institute of Technology, USA), Vulkan Polimac (Polimac Ltd., Godalming, UK), George Hopley, Commodities Research and Michael Zenker, North American Gas and Power Research (Barclays Capital, San Francisco, USA), Nikolai Voropai, Victor Rabchuk, Sergey Senderov, and Natalia Pyatkova (Energy Systems Institute, Irkutsk, Russia), BinBin Jiang (Stanford University, USA), Chen Wenying (Tsinghau University, Beijing, China), Yu Yuefeng (Shanghai Jiaotong University, Shanghai, China), Zeng Lemin (Guangdong Techno- 
economic Research and Development Center, Guangzhou, China), Luiz Augusto Barroso (PSR, Rio de Janeiro, Brasil), Hugh Rudnick (Pontificia Universidad Catolica de Chile, Santiago, Chile), and Niko Iliadis (Energy Consultant, Athens, Greece).

\section{References}

[1] Z. Li, "Natural gas for generation: a solution or a problem?" IEEE Power and Energy Magazine, vol. 3, no. 4, pp. 16-21, July/August 2005.

[2] Z. Li and J. Guo, "Wisdom about age: understanding the aging electricity infrastructure," IEEE Power and Energy Magazine, vol. 4, no. 3, pp. 44-51, May/June 2006.

[3] Energy Information Administration, “International Energy Outlook 2007," available at www.eia.doe.gov.

[4] M. Shahidehpour, Y. Fu, and T. Wiedman, "Impact of natural gas infrastructure on electric power systems," Proceedings of the IEEE, vol. 93, no. 5, pp. 1042-1056, May 2005.

[5] M. Urbina and Z. Li, “A combined model for analyzing the interdependency of electrical and gas systems," Proceedings of the 39th North American Power Symposium, October 2007

[6] Y. Fu, M. Shahidehpour, and Z. Li "Security Constrained Unit Commitment with AC Constraints," IEEE Transactions on Power System, vol. 20, no 3, pp.1538-1550, August 2005.

[7] Y. Fu, M. Shahidehpour, and Z. Li, "AC contingency dispatch based on securityconstrained unit commitment," IEEE Transactions on Power System, vol. 21, no. 2, pp. 897-908, May 2006

[8] Y. Fu, M. Shahidehpour, and Z. Li, "Long-term security-constrained unit commitment: hybrid Dantzig-Wolfe decomposition and subgradient approach," IEEE Transactions on Power System, vol. 20, no. 4, pp. 2093-2106, November 2005

[9] A. Wood and B. Wollenberg, Power Generation, Operation and Control, John Wiley \& Sons, Inc, 2nd edition, 1996.

[10] Hisham Khatib; Financial and Economic Evaluation of Projects in Electricity Supply Industry, 1997.

[11] Statistical data of the Russian Committee for Statistics "Data on the use of fuel resources in 2005".

[12] Order No 156 of 05.07.2007 of the Federal Tariff Service of the RF “On the approval of the guidelines for determination of the gas wholesale price formula".

[13] Energy Strategy of Russia up to 2020 // Energeticheskaya politika. M.: FU IES Ministry for Energy of Russia, 2003. - 136 p.

[14] L.S. Belyaev, Yu.D. Kononov, A.A. Makarov. Methods and Models for Optimization of Energy Systems Development: Soviet Experience, (Review of Energy Models, No. 3, RR-76-18, 1976, pp. 22-33).

[15] J. Michel, J. Arceluz, E. Gordano et al, "IPR/DSM/LCP and Their Effect in Power System Planning" (CIGRE, 1996 Session, report 37-203, 11p.).

[16] S. Hecq, Y. Bouffioulx, P. Doulliez, Ph. Saintes, "The Integrated Planning of the Natural Gas and Electricity Systems Under Market Conditions", (2001 IEEE Porto Power Tech Conference Proceedings, September 10-13, 2001, Porto, Portugal, 4 p.). 
[17] N.I.Voropai, V.I. Rabchuk, S.M.Senderov et al. Assessment of possibilities to ensure national energy security up to 2020. Energeticheskaya politika, 2000, issue 1-2, pp.27-33.

[18] Jensen, J., 2004. The development of a global LNG market. Oxford Institute for Energy Studies NG 5

[19] U.S. Carbon Dioxide Information Analysis Center, U.S. Department of Energy (2007).

[20] China National Bureau of Statistics, 10 January 2006

[21] Noble, Ken et. al.(2005) MARKAL Training Workshop Support Notes, The Australian Bureau of Agricultural and Resource Economics, June 30, 2005.

[22] Jiang et. al "The future of natural gas vs. coal consumption in Beijing, Guangdong, and Shanghai: An assessment in MARKAL" (2007) Program on Energy and Sustainable Energy, Stanford University, Working Paper \#62

[23] Victor, D., Jaffe, A., Hayes, M. 2006. Natural Gas and Geopolitics: From 1970 to 2040. Cambridge University Press, Cambridge, U.K.

[24] IEA - South American Gas - Daring to Tap the Bounty, IEA Press, 2003.

[25] B. Bezerra, R. Kelman, L.A. Barroso, B. Flack, M.L. Latorre, N. Campodonico and M.V. Pereira. "Integrated Electricity-Gas Operations Planning in Hydrothermal Systems". Proceedings of the X Symposium of Specialists in Electric Operational and Expansion Planning, Brazil, 2006, pp. 1-7.

[26] H. Rudnick, "Electricity Generation and Transmission Expansion under Uncertainty in Natural Gas". Proceedings of IEEE 2005 PES General Meeting, San Francisco, 2005, paper 05GM1094, pp. 1-2.

[27] H. Rudnick, L.A. Barroso, C. Skerk, and A. Blanco. "South American Reform Lessons Twenty Years of Restructuring and Reform in Argentina, Brazil and Chile". IEEE Power and Energy Magazine, Vol. 3, (4) July/August 2005, pp. 49-59.

[28] L.A.Barroso, B.Flach, R.Kelman, B.Bezerra, S.Binato, J.M.Bressane, M.V.Pereira "Integrated Gas-Electricity Adequacy Planning in Brazil: Technical and Economical Aspects", Proceedings of IEEE General Meeting 2005, San Francisco, USA, Pages $866-872$.

[29] Energy Community (2005): Conclusions of 3rd Permanent High-Level Group (PHLG) Meeting 5 December 2006, Vienna.

[30] Energy Community (2005): Bottlenecks of SEE Gas Market \& Challenges, Donors Meeting.

[31] Energy Community (2006): New Gas Infrastructure Investment Regulation (NGIIR).

[32] Energy Community (2007): Implementation of the Treaty 


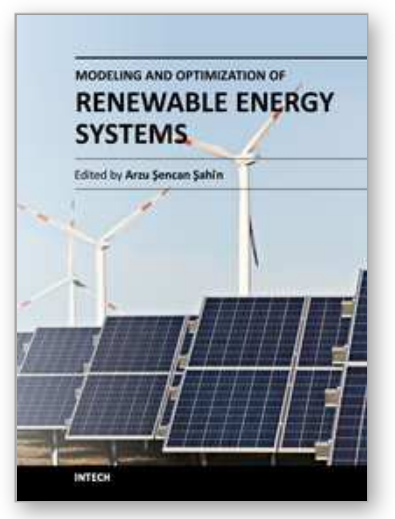

\author{
Modeling and Optimization of Renewable Energy Systems \\ Edited by Dr. Arzu Şencan
}

ISBN 978-953-51-0600-5

Hard cover, 298 pages

Publisher InTech

Published online 11, May, 2012

Published in print edition May, 2012

This book includes solar energy, wind energy, hybrid systems, biofuels, energy management and efficiency, optimization of renewable energy systems and much more. Subsequently, the book presents the physical and technical principles of promising ways of utilizing renewable energies. The authors provide the important data and parameter sets for the major possibilities of renewable energies utilization which allow an economic and environmental assessment. Such an assessment enables us to judge the chances and limits of the multiple options utilizing renewable energy sources. It will provide useful insights in the modeling and optimization of different renewable systems. The primary target audience for the book includes students, researchers, and people working on renewable energy systems.

\title{
How to reference
}

In order to correctly reference this scholarly work, feel free to copy and paste the following:

Thomas J. Hammons (2012). Globalization of the Natural Gas Market on Natural Gas Prices in Electric Power Generation and Energy Development, Modeling and Optimization of Renewable Energy Systems, Dr. Arzu Şencan (Ed.), ISBN: 978-953-51-0600-5, InTech, Available from: http://www.intechopen.com/books/modelingand-optimization-of-renewable-energy-systems/globalization-of-the-natural-gas-market-on-natural-gas-pricesin-electric-power-generation-and-energ

\section{INTECH}

open science | open minds

\author{
InTech Europe \\ University Campus STeP Ri \\ Slavka Krautzeka 83/A \\ 51000 Rijeka, Croatia \\ Phone: +385 (51) 770447 \\ Fax: +385 (51) 686166 \\ www.intechopen.com
}

\author{
InTech China \\ Unit 405, Office Block, Hotel Equatorial Shanghai \\ No.65, Yan An Road (West), Shanghai, 200040, China \\ 中国上海市延安西路65号上海国际贵都大饭店办公楼405单元 \\ Phone: +86-21-62489820 \\ Fax: +86-21-62489821
}


(C) 2012 The Author(s). Licensee IntechOpen. This is an open access article distributed under the terms of the Creative Commons Attribution 3.0 License, which permits unrestricted use, distribution, and reproduction in any medium, provided the original work is properly cited. 